Review

\title{
Conotoxins Targeting Nicotinic Acetylcholine Receptors: An Overview
}

\author{
Eline K. M. Lebbe, Steve Peigneur, Isuru Wijesekara and Jan Tytgat * \\ Toxicology and Pharmacology, KU Leuven (University of Leuven), O\&N2 P.O.Box 922, \\ Herestraat 49, 3000 Leuven, Belgium; E-Mails: eline.lebbe@pharm.kuleuven.be (E.K.M.L.); \\ steve.peigneur@pharm.kuleuven.be (S.P.); wijesekaraliyanageisuru.wijesekara@pharm.kuleuven.be (I.W.) \\ * Author to whom correspondence should be addressed; E-Mail: jan.tytgat@pharm.kuleuven.be; \\ Tel.: +32-16-323404; Fax: +32-16-323405.
}

Received: 31 March 2014; in revised form: 24 April 2014 / Accepted: 28 April 2014 /

Published: 22 May 2014

\begin{abstract}
Marine snails of the genus Conus are a large family of predatory gastropods with an unparalleled molecular diversity of pharmacologically active compounds in their venom. Cone snail venom comprises of a rich and diverse cocktail of peptide toxins which act on a wide variety of ion channels such as voltage-gated sodium- $\left(\mathrm{Na} \mathrm{v}_{\mathrm{V}}\right.$, potassium$\left(\mathrm{K}_{\mathrm{V}}\right)$, and calcium- $\left(\mathrm{Ca}_{\mathrm{V}}\right)$ channels as well as nicotinic acetylcholine receptors (nAChRs) which are classified as ligand-gated ion channels. The mode of action of several conotoxins has been the subject of investigation, while for many others this remains unknown. This review aims to give an overview of the knowledge we have today on the molecular pharmacology of conotoxins specifically interacting with nAChRs along with the structure-function relationship data.
\end{abstract}

Keywords: nicotinic acetylcholine receptor; cone snail toxins; $\alpha$-conotoxins; mode of action; working mechanism; acetylcholine binding protein; crystallography; docking model

\section{Cone Snails, the New Gold Mines?}

In general, venom peptides offer a unique and extensive source of chemical diversity as they are driven by evolutionary pressure to improve prey capture and/or protection of the species. This chemical diversity can be found in animals as diverse as sea anemones, jellyfish, spiders, scorpions, cone snails, etc. [1]. Among these species, venoms from cone snails (genus Conus) can be seen as an 
untapped cocktail of biologically active compounds that are increasingly recognized as an emerging source of peptide-based therapeutics. Their ability to use a diverse array of small disulfide-bridged peptides (conopeptides or conotoxins) for prey capture makes them unique. Moreover, they are considered as specialized predators which have developed the most sophisticated peptide chemistry and neuropharmacology for their own biological purposes by producing venoms that contain a structural and functional variety of neurotoxins.

Conotoxins display a great molecular diversity, being evolved across all phylogenetic clades and feeding strategies of cone snails. This multiplicity is mirrored in the classification of at least 16 genetically distinct superfamilies where the conotoxins are categorized upon their cysteine-framework. These superfamilies are subdivided in conotoxin families depending on their impressive diversity of targets ranging from voltage-gated ion channels (sodium, potassium, and calcium) to ligand-gated ion channels (such as nicotine receptors and serotonin receptors). The implementation of this broad spectrum of pharmacologically active components has made this single genus very successful, evolving into more than 500 Conus species [2]. Each cone snail species produces more than 1000 conopeptides with an estimated overlap of $5 \%$ between different species [3]. To date, only $0.1 \%$ out of potentially 500,000 venom components has been functionally and structurally investigated. Nevertheless, the consideration of Conus venoms as gold mines for the discovery of new therapeutics is validated by the knowledge that, out of the limited number of studied conopeptides, already six peptides have reached human clinical trials, and one was approved as analgesic in 2004. The toxins of Conus sp. are usually potent, selective and small (typically $<5 \mathrm{kDa}$ ) which is an advantage for cost-effective synthesis and makes them ideal pharmacological probes [4].

This review will focus on one conotoxin family in particular, namely the $\alpha$-conotoxins. These toxins are nicotinic acetylcholine receptor (nAChR) antagonists that are used by the cone snails to immobilize their prey. Here, we discuss the structure-function relationship and molecular pharmacology of $\alpha$-conotoxins specifically interacting with nAChRs.

\section{Alpha-Conotoxins, the Largest Characterized Group of Conotoxins}

Conus species have evolved multiple classes of conopeptides targeting ligand-gated ion channels including nicotinic acetylcholine receptors (nAChRs), 5-hydroxytryptamine3 receptors (5-HT $\mathrm{Hs}_{3}$, and $N$-methyl-D-aspartate (NMDA) antagonists as well as $\alpha$-amino-3-hydroxy-5-methyl-4-isoxazole propionic acid (AMPA) enhancers. Among these receptor classes, antagonists of nAChRs are the largest and most diverse. Moreover, along with the NMDA antagonists, they show the highest potential as lead compounds to new ligand-gated ion channel therapeutics [5].

In almost every Conus venom investigated until now, at least one conotoxin that inhibits nAChRs was found [6,7]. Because many of the known prey of Conus use cholinergic transmission at their neuromuscular junctions, it is believed that the venom of each cone snail species contains at least one nAChR antagonist. The great majority of the $>500$ species of cone snails paralyzes polychaete worms, others paralyze mollusks and various invertebrates such as echiuroid worms and hemichordates. A minority use their venom to prey on fish. Each cone snail species is specialized because they often eat exclusively one prey species [8]. Overall, seven different families of conotoxins are known to target nAChRs. The largest group of characterized Conus sp. peptides is the family of $\alpha$-conotoxins 
(belonging to the A-superfamily), that are selective antagonists of the muscle and neuronal subtype nAChRs [6]. They act at the nAChR acetylcholine binding site as competitive antagonists and are among the smallest of the conopeptides (12-20 amino acid residues) [6,9]. Alpha-conotoxins have a characteristic CC- $\mathrm{X}_{m}-\mathrm{C}-\mathrm{X}_{n}-\mathrm{C}$ framework, where the four cysteines can yield three possible disulfide connectivities: globular (I-III, II-IV), ribbon (I-IV, II-III) and beads (I-II, III-IV). However, naturally appearing $\alpha$-conotoxins typically exhibit the globular conformation [10]. The number of residues included within the two loops $(m, n)$ of $\alpha$-conotoxins is the basis for the division into several structural subgroups $(m / n: 3 / 5,4 / 3,4 / 4,4 / 5,4 / 6$ and 4/7). The loop size is believed to roughly correlate with the pharmacological target selectivity. In general, $\alpha$-conotoxins with a $3 / 5$ framework are isolated from fish-hunting snails and are active toward fish and/or mammalian neuromuscular nAChRs, whereas conotoxins from the $4 / 3,4 / 4,4 / 5,4 / 6$ or 4/7 classes mainly interact with mammalian neuronal nAChRs [9]. The most commonly reported framework is the 4/7 subgroup. Within this subgroup, an interesting $\alpha$-conotoxin is Vc1.1 which potently inhibits neuronal $\left(\alpha_{3}, \alpha_{5}, \alpha_{7}, \beta_{4}\right.$ and $\alpha_{9} \alpha_{10} \mathrm{nAChR}$ subunits) versus muscle nAChRs [11,12] (Figure 1). Therefore, it was selected for tests in pain models revealing Vc1.1 as the first $\alpha$-conotoxin with an analgesic effect $[13,14]$.

Figure 1. $\alpha$-conotoxin Vc1.1 three-dimensional NMR solution structure (PDB:2H8S) and amino acid sequence representation with indication of the two disulfide bonds. Figure was prepared using the program PyMOL [15].
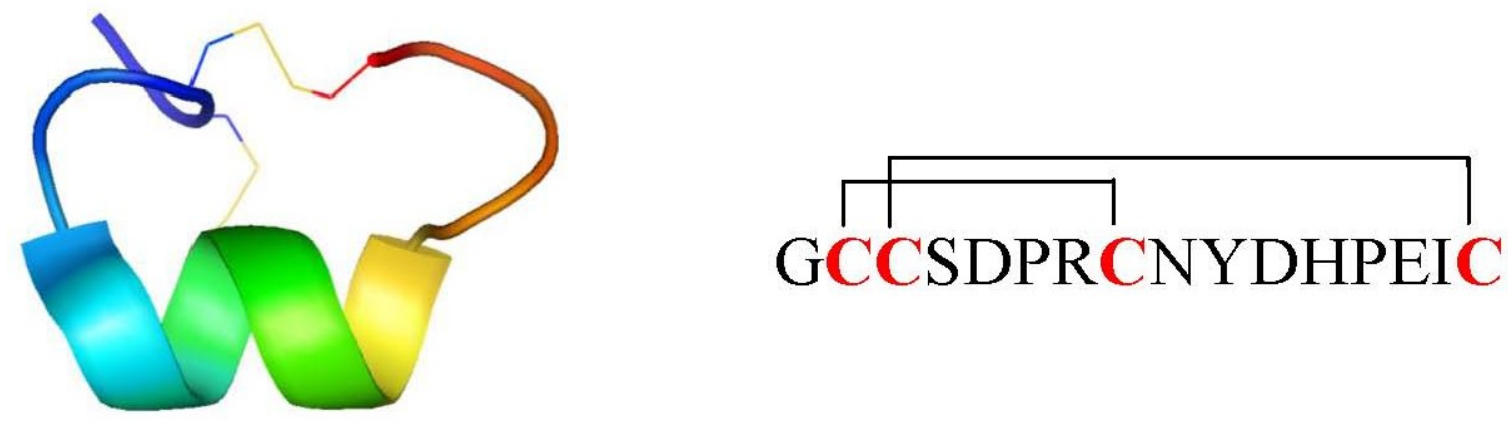

The gene structure of A-superfamily conotoxins is unique as it is the only superfamily having one intron in between two exons, while most conotoxin superfamily genes contain two introns [16]. In general, members from the same superfamily share a highly conserved signal peptide (pre-region) whereas the pro-region is less preserved. In $\alpha$-conotoxins, the large intron can be found in this pro-region. Finally, the $C$-terminal toxin-encoding region is highly variable $[16,17]$.

Alpha-conotoxins that are selective for a specific nAChR significantly contributed to their characterization both in vivo and in vitro, and some of these specific peptides may possess therapeutic potential [11]. The pharmacophore of these $\alpha$-conotoxins has been investigated in detail. It is composed of a conserved hydrophobic patch in the first loop which determines binding, and a more variable second loop, which administers selectivity through pairwise interactions with different nAChRs subunits [18]. In this way, the selectivity of $\alpha$-conotoxins isolated from different Conus species not only contributed to their characterization but also enabled the dissection of the functional roles of nAChR subtypes [6,9]. 


\section{Nicotinic Acetylcholine Receptors (nAChRs)}

Chemical signaling in the central and peripheral nervous systems is mediated by rapid opening and closing of pentameric ligand-gated ion channels (pLGICs). This ion channel family includes nicotinic acetylcholine (nAChRs), serotonin-type-3 (5- $\left.\mathrm{HT}_{3} \mathrm{Rs}\right), \gamma$-aminobutyric acid-A (GABA $\left.{ }_{\mathrm{A}} \mathrm{Rs}\right)$, and glycine receptors (GlyRs) [19]. All these receptors exist in at least three distinct states which are interconvertible: resting (unliganded, closed channel), activated (liganded, open channel), and desensitized (liganded, closed channels). The binding of agonists, antagonists and allosteric drugs alters the equilibria between these interconvertible states. Cys-loop LGICs are compiled of five identical or homologous subunits arranged pseudosymmetrically around a central ion-conducting channel, like staves around a barrel. When a neurotransmitter binds in the extracellular ligand-binding domain, rapid opening of an intrinsic ion channel in the transmembrane domain of the receptor is triggered. With prolonged neurotransmitter exposure, the channel shifts to a non-conducting desensitized state [20].

Nicotinic acetylcholine receptors, being a member of ligand-gated cationic channels, mediate fast synaptic transmission. They are broadly distributed throughout the peripheral and central nervous systems of both simple and evolutionarily complex organisms [21]. As these structures are highly conserved over a wide range of species, the importance of nAChRs in the nervous system cannot be neglected. Moreover, this general appearance also provides a platform for translational research from in vitro ligand discovery to in vivo characterization in various animal models of human diseases [22]. Examples of these diseases include central nervous system (CNS) disorders such as epilepsy, Alzheimer's disease, Parkinson's disease, schizophrenia, nicotine addiction, pain, cancer, etc. [23-26]. The contribution of nAChRs disorders to the above mentioned pathophysiologic states can be found in the fact that presynaptic nAChRs induce various brain regions to release several neurotransmitters, including dopamine, norepinephrine, serotonin and acetylcholine [21].

The development of nAChR agonists began in the early 1990s after the discovery of nicotine's positive effects. ABT-418, designed by Abbott Labs, was one of the first in a row of nAChR agonists examined as a possible treatment of Alzheimer's disease, Parkinson's disease and attention-deficit hyperactivity disorder (ADHD) [27]. Several other antagonist drugs such as varenicline in Champix ${ }^{\circledR}$ and Chantix ${ }^{\circledR}$ and nicotine patches are known today to treat tobacco dependence [28]. Drugs like galantamine in Razadyne ${ }^{\circledR}$, Nivalin ${ }^{\circledR}$ are used to treat dementia caused by Alzheimer's disease. However, its primary mode of action is as an acetylcholine esterase inhibitor. Several other compounds are in clinical trials $[29,30]$.

In mammals, there are 16 different nAChR subunits: nine different $\alpha$-subunits $\left(\alpha_{1-7}, \alpha_{9}\right.$ and $\left.\alpha_{10}\right)$, four $\beta$-subunits $\left(\beta_{1-4}\right)$, as well as $\gamma, \delta$ and $\varepsilon$ subunits. Five of these subunits combine to form muscle nAChR subtypes $\left(\alpha_{1} \beta_{1} \gamma \delta\right.$ and $\left.\alpha_{1} \beta_{1} \delta \varepsilon\right)$ which are found at neuromuscular junctions, whereas the rest $\left(\alpha_{2}-\alpha_{10}, \beta_{2}-\beta_{4}\right)$ assemble in numerous homomeric (having exclusively $\alpha$-subunits) or heteromeric (having $\alpha$ - and $\beta$-subunits) neuronal nAChR subtypes [26]. The assembly of different pentamers forms a complex variety of nAChR subtypes with different pharmacological and biophysical properties. For example, heteromeric receptor subtypes exhibit two distinct subunit stoichiometries of $\alpha$ : $\beta$ ratios $(2: 3$ or $3: 2$ ), each with distinct functional properties that will contribute to synaptic regulation for nicotinic signaling in the mammalian brain [25,31,32]. The diversity increases even further when more than one $\alpha$ or $\beta$ subunit is included within the same pentamer (for example, $\alpha_{6} \alpha_{5} \beta_{3}$ or $\alpha_{6} \beta_{2} \beta_{3}$ ) [25]. In general, 
each subunit of a nAChR can be divided into two parts: an extracellular binding domain (ECD) folded into a $\beta$-sandwich core, and a transmembrane channel domain (TMD) consisting of four $\alpha$-helical membrane-spanning segments (M1-M4). Each eukaryotic nAChR subunit also contains an intracellular domain (ICD) consisting of $~ 100$ amino acids defined as the M3-M4 loop (Figure 2) [33]. In each subunit, four flexible loops (loop2, loop7, loop9, and the M2-M3 loop) connect the binding domain to the channel domain and play a crucial role in the coupling of binding site movements to the channel. The binding of neurotransmitter occurs at interfaces between two subunits in the ECD. The M2 helix of each of the subunits forms the ion-conducting channel [19].

Figure 2. Structure and function of the nicotinic acetylcholine receptor. (A) Schematic representation of receptor subunits arranged around a central cation-conducting pore. The ligand binding sites are formed at the interface of two subunits. (B) Illustration of a single nAChR subunit embedded in the membrane. (C) Representation of the protein structure of the pentameric nAChR obtained from T. marmorata (PDB 2BG9) in the plasma membrane. The location and function of the major receptor domains are indicated. A single subunit is highlighted in purple using visual molecular dynamics (VMD). Reproduced from Kabbani et al. (2013) [33], with permission from (C) 2013 WILEY Periodicals, Inc.

A)

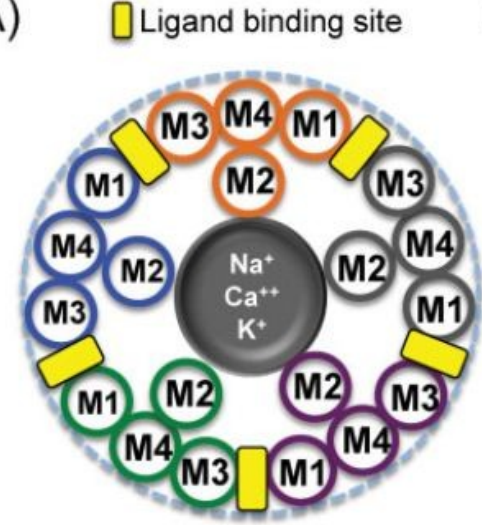

C)

\section{Extracellular Domain -Ligand binding -Post-translational modification -Cys-loop \\ Intracellular Domain \\ -Protein Interaction \\ -Cell signaling \\ -Receptor trafficking \\ -Receptor phosphorylation}

B) $\quad \mathrm{N}$
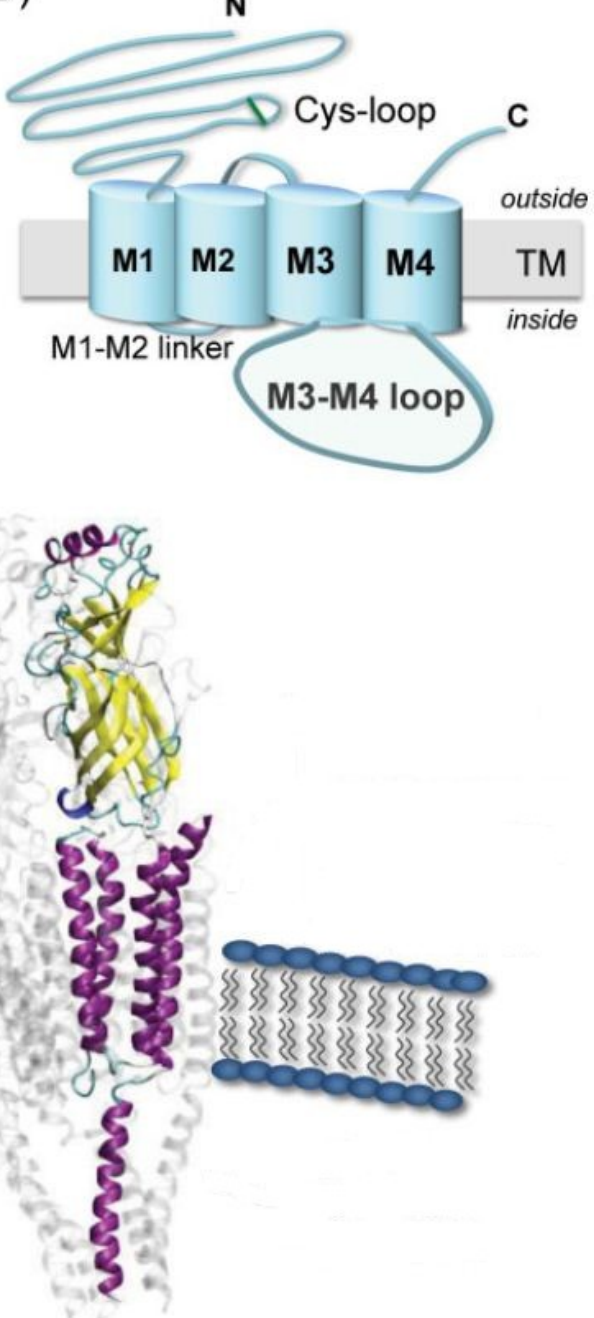
Investigating how $\alpha$-conotoxins interact with their targets and which amino acids are important is a challenging research domain. Nevertheless, this information is priceless in the quest for novel and selective therapeutics. In the next sections, we describe the different tools used to determine the mode of action of these $\alpha$-conotoxins and the important structure-function relationship findings considering $\alpha$-conotoxins selectively targeting nAChRs.

\section{4. $\alpha$-Conotoxins and Their Mode of Action-State of the Art}

The most important milestones in the determination of the mode of action of $\alpha$-conotoxins are (i) the discovery of the cryo-electron microscopy structures of the Torpedo nAChR in both a presumed unliganded closed state ( $4 \AA$ resolution) and liganded open state ( $6.2 \AA$ resolution) by Unwin and colleagues (2005) [34,35] and (ii) the reporting of the first crystal structure of the acetylcholine binding protein (AChBP) of Lymnaea stagnalis in Nature (2001) by Brejc and colleagues [36] (Figure 3). AChBPs are a class of water-soluble proteins that display significant sequence homology with the ligand-binding domain of $\alpha_{1}$ or $\alpha_{7}$ nAChRs [37]. The AChBP crystal structure of Brejc and colleagues elegantly reveals the three-dimensional organization of the ACh binding site at $2.7 \AA$ [36]. Since this pioneering work, the structures of $\mathrm{AChBP}$ from two other mollusk species and in complex with various ligands have become available. This significantly increased the interest in this protein [38-41].

Both structures (Torpedo and AChBP) provide excellent tools to model the $\alpha$-conotoxin/nAChR interactions, but the latter one is currently most used.

Figure 3. AChBP three-dimensional structure (PDB:1I9B) (A) Top view and (B) side view of the Lymnaea stagnalis AChBP. Figures were prepared using the program PyMOL [15].
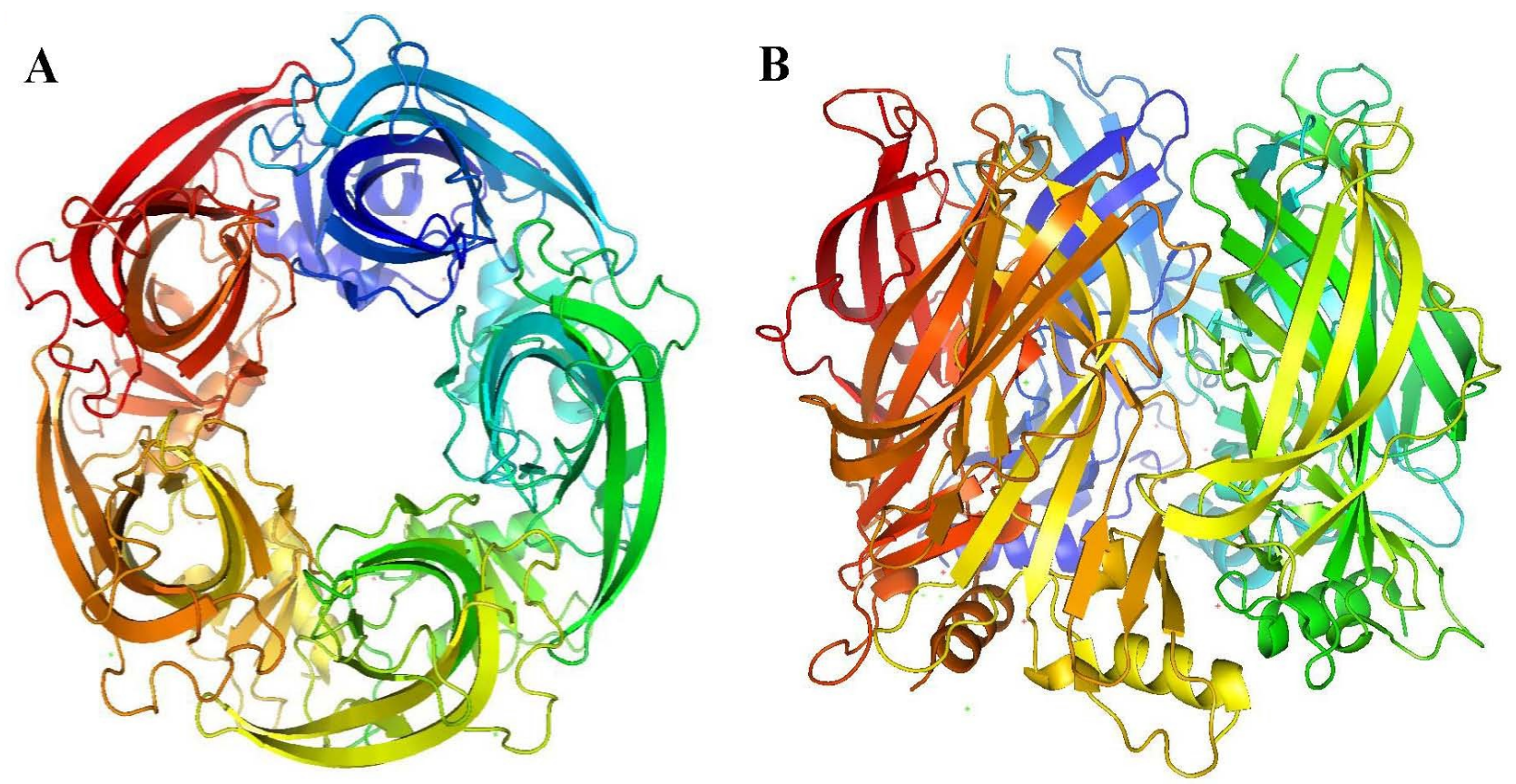

The discovery and description of several X-ray crystal structures of AChBP/ $\alpha$-conotoxin complexes considerably advanced the knowledge of the structural basis for the nAChR subtype selectivity of $\alpha$-conotoxins. Three conotoxins, ImI [42], PnIA [43] and [A10L]TxIA [7], which have a divergent 
primary sequence, showed a similar orientation within the ACh binding pocket when they were co-crystallized with AChBP. All of them demonstrated an important contribution of hydrophobic contacts between a conserved proline, several hydrophobic residues of the $\alpha$-conotoxins and several residues in the aromatic cage of $\mathrm{AChBP}$. Consequently, specific electrostatic interactions and hydrogen bonds formed between the $\alpha$-conotoxin and the nAChR subunits showed to give rise to different $\mathrm{nAChR}$ selectivity profiles [5]. For example, $\alpha$-conotoxin [A10L]TxIA displays a unique electrostatic pairing between $\mathrm{Arg}^{5}$ and AChBP-Asp ${ }^{195}$, which is used to achieve the high-affinity binding of [A10L]TxIA (Figure 4) [7]. Moreover, the nAChR subtype selectivity of [A10L]TxIA is thought to arise from a tilt in the orientation of the $\alpha$-conotoxin structure within the ACh binding pocket.

Figure 4. $\alpha$-Conotoxin [A10L]TxIA co-crystallized with the Aplysia california AChBP (Ac-AChBP). (A) Top view crystal structure of the $A c-\mathrm{AChBP}$ in complex with [A10L]TxIA (shown in red). (B) Detailed view of the molecular interactions that results in the different backbone orientations of [A10L]TxIA. Reproduced from Dutertre et al., (2007) [7], with permission from (C) 2007 EMBO.
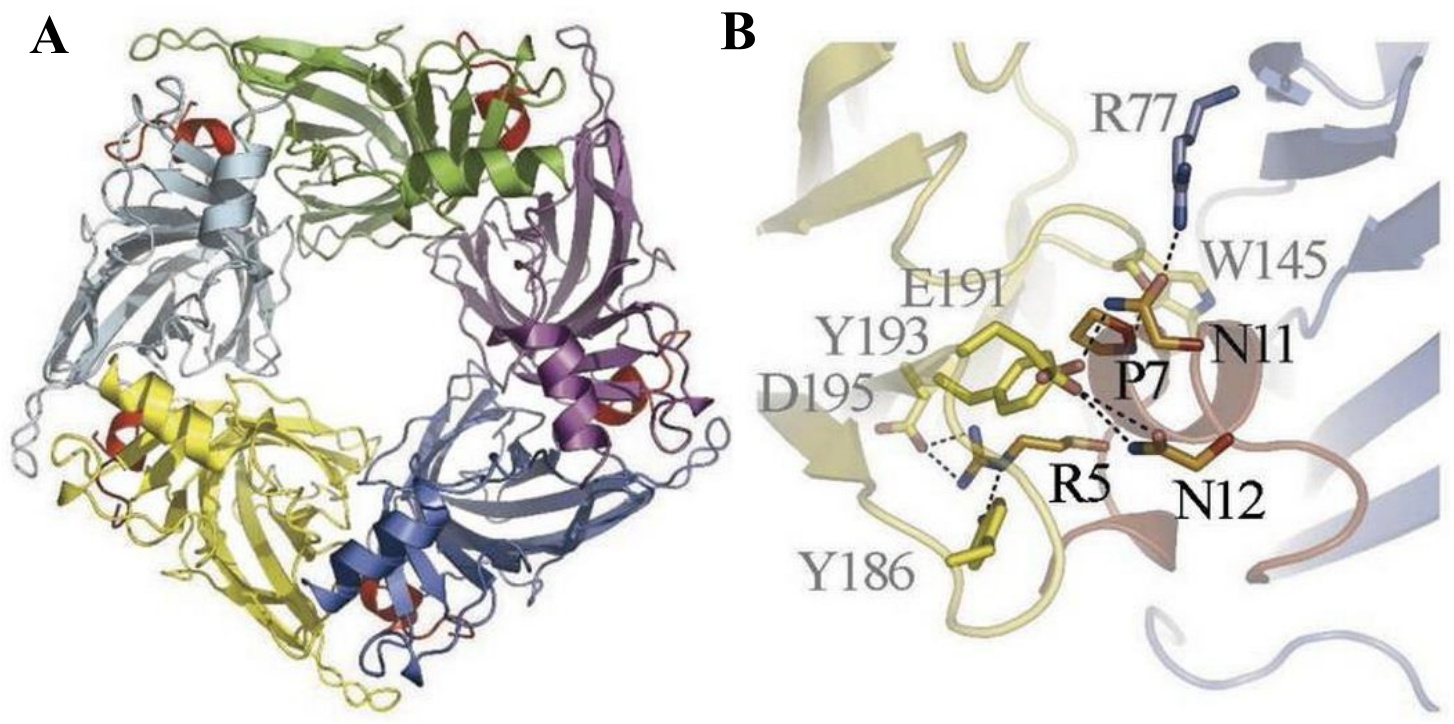

\section{Alpha-Conotoxins and Their Mode of Action}

Structure-function activity studies on $\alpha$-conotoxins appeared in the early 1990 s and were mostly alanine-scanning mutagenesis or amino-acid substitution studies. Later, with the crystal structure of the AChBP being available, these investigations were combined with molecular docking studies. In 2001, shortly after the publication of the first AChBP structure, Harel et al. (2001) modeled the interaction of a snake toxin with the nAChR [44]. At this aim, they used NMR data on a complex between $\alpha$-bungarotoxin, a nicotinic antagonist found in snake venom, and a nAChR peptide mimotope. The complex was then superimposed to the AChBP crystal structure to reveal several important interactions with AChBP loops and side chains. Thanks to the different AChBP structures now available, key interactions as seen in AChBP-ligand co-crystal structures give a clear view of the minimum pharmacophore residues required for binding. The first model of the interaction between an $\alpha$-conotoxin and nAChRs was described by Dutertre et al. [45], based on docking simulations and 
distance restrains obtained from mutagenesis data. It has been shown that antagonists such as $\alpha$-conotoxins make extensive contacts with receptor residues located outside the conserved pocket, whereas agonists appear to make few contacts. Therefore, antagonists allow the design of specific interactions with unique amino acids, as they achieve high subtype selectivity. Here, we describe several studies indicating the interaction of $\alpha$-conotoxins with neuronal nAChRs $\left(\alpha_{7}, \alpha_{3} \beta_{2}, \alpha_{3} \beta_{4}, \alpha_{4} \beta_{2}\right.$, $\alpha_{6}$-containing nAChRs and $\left.\alpha_{9} \alpha_{10}\right)$ and muscle subtype nAChRs $\left(\alpha_{1} \beta_{1} \gamma \delta\right.$ and $\left.\alpha_{1} \beta_{1} \delta \varepsilon\right)$. To the best of our knowledge, specific interactions of $\alpha$-conotoxins with the $\alpha_{2}$ subunit have not yet been described.

\subsection{Neuronal Subtype nAChRs}

\subsection{1. $\alpha_{7}$ nAChRs Selective $\alpha$-Conotoxins}

One of the neuronal nAChRs, $\alpha_{7}$, has received much attention since its discovery [46]. This is due to their distribution in the brain, including regions involved in learning and memory, the hippocampus and the cerebral cortex [47-49]. Consequently, $\alpha_{7} \mathrm{nAChR}$ dysfunctions have been implicated in a variety of severe pathologies such as certain types of epilepsy, myasthenic syndromes, schizophrenia, Parkinson's and Alzheimer's diseases [21,50,51]. The binding sites of $\alpha_{7} \mathrm{nAChRs}$ are formed at the interfaces between identical $\alpha_{7}$ subunits in a homopentameric channel. The residues of the $\alpha$ face of the binding site, termed the $(+)$ face, cluster in three well separated regions of the primary sequence, named loops A, B, and C [52] (Figure 5). The stabilization in the AChBP is established based on the vicinal disulfide bonds in loop $\mathrm{C}$, where the $\alpha$-conotoxin disulfide bond Cys I-III interacts [53].

Figure 5. Structure of one subunit of the $\alpha_{7} \mathrm{nAChR}$. The different loops $(\mathbf{A}-\mathbf{E})$ and the cys-loop in the extracellular domain as well as the M1-M4 segments in the transmembrane domain and M3-M4 linker in the intracellular domain are indicated. Reproduced from Taly et al. (2006) [54], with permission from (C) 2006 by The National Academy of Sciences of the USA.

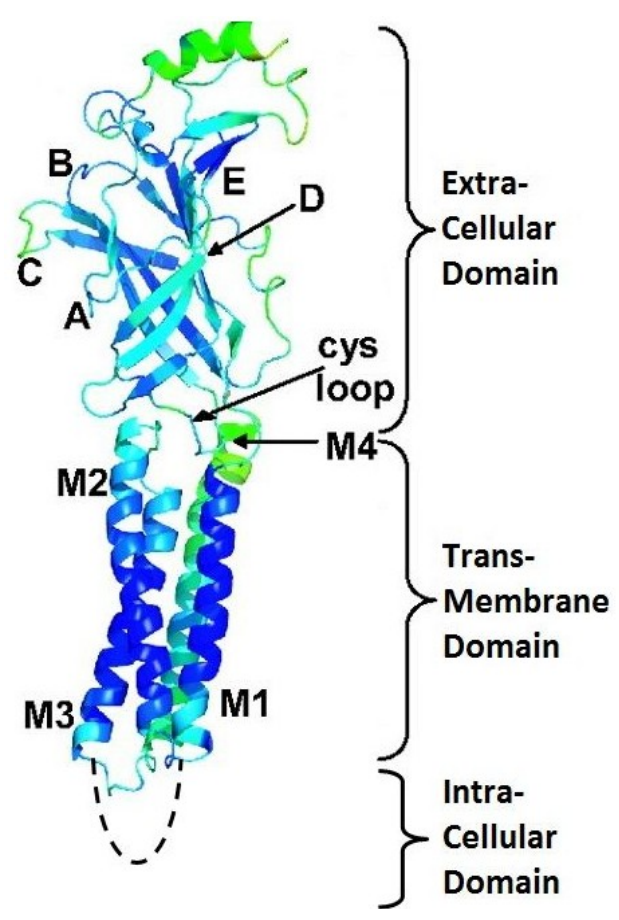


One of the first structure-activity relationship studies on $\alpha$-conotoxins was performed on the closely related conotoxins PnIA and PnIB (C. pennaceus, Figure 6) [55]. The sequences of these toxins differ by only two amino acids, namely Ala versus Leu and Asn versus Ser at position 10 and 11 respectively. Remarkably, PnIA is more potent for $\alpha_{3} \beta_{2}$ nAChRs, whereas PnIB binds preferentially to $\alpha_{7}$ nAChRs. Hogg et al. (1999) [56] and Luo (1999) [57] demonstrated that a Leu for Ala substitution at position 10 makes PnIA a highly selective inhibitor of the $\alpha_{7}$ subtype ( $\mathrm{IC}_{50}$ of $168 \mathrm{nM}$ ). Later, Hogg et al. (2003) [58] showed that changing a single amino acid side-chain at position 10 of PnIA is sufficient to alter the toxin specificity for receptor states in the $\alpha_{7}{ }^{\mathrm{L} 247 \mathrm{~T}}$ mutant. Moreover, the A10L mutation in PnIA changed its properties from antagonistic to agonistic behavior in the $\alpha_{7}^{\text {L247T }} \mathrm{nAChR}$. The [A10L,D14K]PnIA variant, which behaves similarly to PnIA, was the first conotoxin being co-crystallized in complex with its receptor environment. The toxin was bound to the Ac-AChBP and demonstrated that the protein is mostly buried in the ligand-binding cavity and that no toxin residues are in contact with the AChBP exterior (Figure 7). The $N$-terminal part is positioned toward the bottom side of AChBP whereas the central helix protrudes into the binding site interior. The $C$-terminus is located at the top of the binding site with amino acid residues Lys ${ }^{14}-\mathrm{Cys}^{16}$ near the outside of the ligand-binding site. The $\mathrm{Cys}^{2}-\mathrm{Cys}^{8}$ disulfide bond is stacked on the $\mathrm{Cys}^{188}{ }^{18 y}{ }^{189}$ disulfides of the AChBP [43].

Figure 6. Sequence alignment of PnIA, PnIB, ImI, ArIB, LsIA and MrIC. Disulfide bridges are indicated with black lines above the sequences. Dashes are put to make all sequences and intercysteine loops of comparable length. The first column indicates the different conotoxins discussed in this section, the second column the name of the Conus species and the third column the according amino acid sequence. Loop 1 and loop 2 are labeled below the amino acid sequences. Bold letters are amino acid residues important for $\alpha$-conotoxin interaction as discussed in this section.

\begin{tabular}{|c|c|c|}
\hline $\operatorname{PnIA}$ & C. pennaceus & -GCCSLPPCAANNPDYC--- \\
\hline $\operatorname{PnIB}$ & C. pennaceus & -GCCSLPPCALSNPDYC--- \\
\hline $\operatorname{ImI}$ & C. imperialis & -GCCSDPRCAWR----C--- \\
\hline ArIB & C. arenatus & DECCSNPACRVNNPHVCRRR \\
\hline LSIA & C. Iimpusi & SGCCSNPACRVNNPNIC--- \\
\hline $\operatorname{MrIC}$ & C. marmoreus & PECCTEPAC $\underbrace{H V S N P E L C---~}_{\text {Loop } 1}$ \\
\hline
\end{tabular}

Quiram et al. (2000) demonstrated the existence of a dominant interaction between the $\alpha$-conotoxin PnIB (C. pennaceus, Figure 6) $\mathrm{L}^{10}$ and $\alpha_{7} \mathrm{~W}^{149}$ (located in loop B of the $(+$ ) face of the binding site) and weaker interactions between $\mathrm{P}^{6}$ and $\mathrm{P}^{7}$ of PnIB and $\alpha_{7} \mathrm{Y}^{93}$ (located in loop A of the $(+)$ face of the binding site) [59]. The authors state the importance of a hydrophobic contribution of residue 10 to the activity towards the receptor. Their overall results placed into close proximity the aromatic side chains $\mathrm{W}^{149}, \mathrm{Y}^{93}$ and $\mathrm{Y}^{151}$ found on the $(+)$ face of the $\alpha_{7}$ binding site, and suggested similar interactions for 
related $\alpha$-conotoxins. The specificity of conotoxin PnIB for $\alpha_{7}$ receptors is due to its rigid scaffold that presents a hydrophobic spiral of side chains to the $(+)$ face of the $\alpha_{7}$ binding site.

Figure 7. Representation of two $\alpha$-conotoxins co-crystallized with $A c$-AChBP. Comparison of the $A c$-AChBP surface contact area of $\alpha$-conotoxins [A10L,D14K]PnIA (A) and $\operatorname{ImI}(\mathbf{B})$ In the pictures below $(\mathbf{C}$ and $\mathbf{D})$, the surface area presentation of both $\alpha$-conotoxins, (C) [A10L, D14K]PnIA and (D) ImI, protruding in the binding site is shown. $\operatorname{Arg}^{7}$ and $\operatorname{Trp}^{10}$ of ImI are depicted in stick presentation. Reproduced from Ulens et al., (2006) [42], with permission from (C) 2006 by The National Academy of Sciences of the USA.

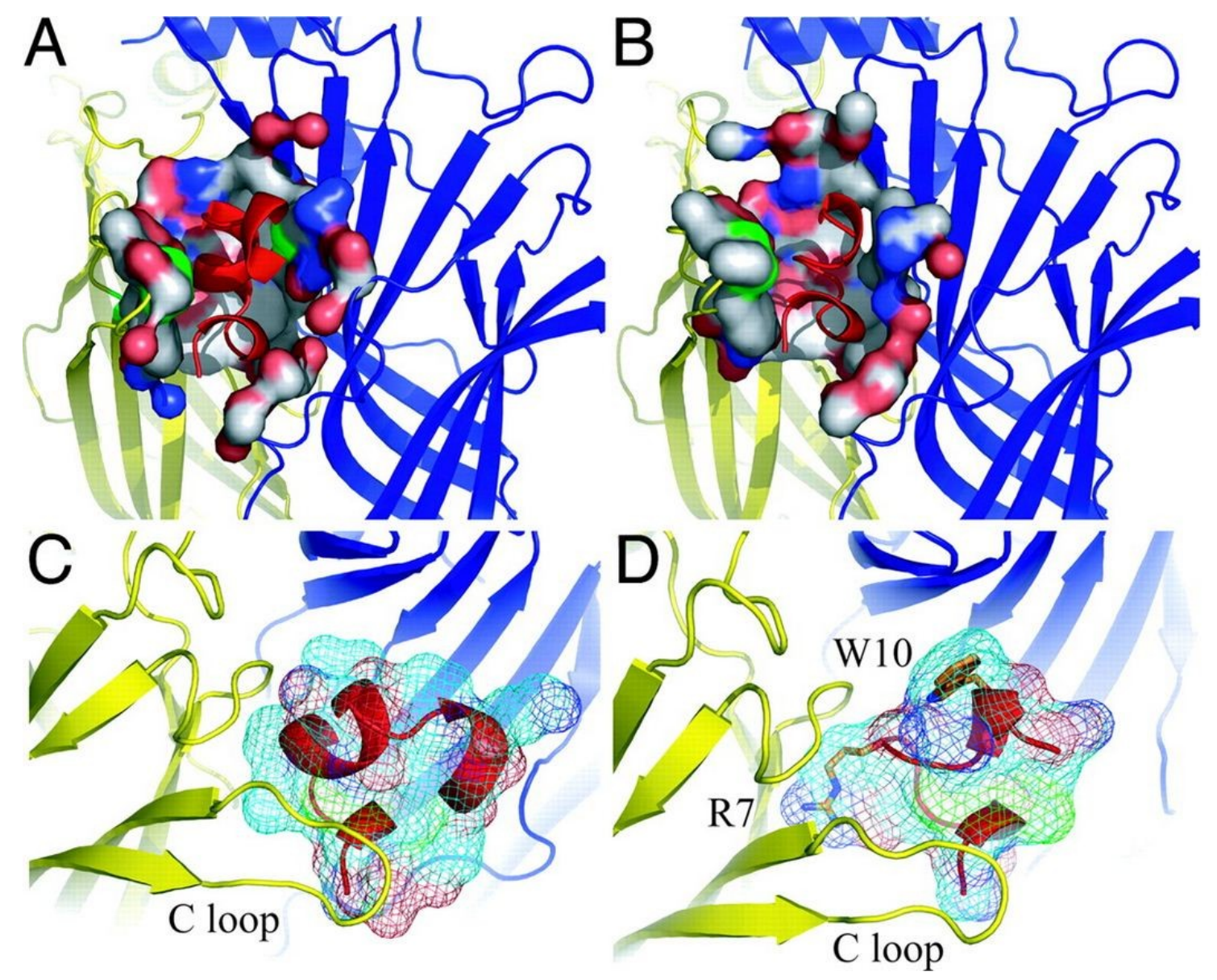

Another $\alpha$-conotoxin for which structure-activity relationship studies were performed is $\operatorname{ImI}$ (C. imperialis, Figure 6). Quiram et al. (1998) identified several determinants (Asp ${ }^{5}, \mathrm{Pro}^{6}, \mathrm{Arg}^{7}$, and $\operatorname{Trp}^{10}$ ) which influence potency of $\operatorname{ImI}$ at the $\alpha_{7} \mathrm{nAChR}[60,61]$ (Figure 7). The pairwise interactions between ImI and $\alpha_{7} \mathrm{nAChRs}$ were determined later by thermodynamic mutant cycle analysis [62]. These results revealed a major interaction between $\mathrm{Arg}^{7}$ of $\operatorname{ImI}$ and $\alpha_{7} \mathrm{Tyr}^{195}$, accompanied by smaller contributions between $\mathrm{Asp}^{5}$ of $\operatorname{ImI}$ and $\alpha_{7} \operatorname{Trp}^{149}, \alpha_{7} \operatorname{Tyr}^{151}$ and $\alpha_{7} \mathrm{Gly}^{153}$. Other interactions were found between $\operatorname{Trp}^{10}$ of ImI and $\alpha_{7} \mathrm{Thr}^{77}$ and $\alpha_{7} \mathrm{Asn}^{111}$. These binding interfaces and conformations were confirmed in co-crystallization experiments of ImI and AChBP [42,63]. Armishaw et al. (2010) used a three-step synthetic combinatorial strategy to study a specific region (i.e., the $n$-loop AWR) of $\alpha$-conotoxin ImI to develop novel analogs with improved antagonist properties for the $\alpha_{7} \mathrm{nAChR}$. They 
found that substitutions of $\mathrm{Ala}^{9}$ with Nva (norvaline) or Leu residues were optimal for $\alpha_{7} \mathrm{nAChR}$ activity, whereas the presence of an aromatic residue at the $\operatorname{Trp}^{10}$ position was observed to be crucial for optimal receptor binding. Substitutions in the $\mathrm{Arg}^{11}$ position had minor effects on antagonistic potency. The most significant increases in antagonist potency were observed for analogs containing the $\mathrm{Nva}^{9}-\mathrm{Dmt}^{10}-\mathrm{His}^{11}$ (Dmt: 2,6-dimethyltyrosine), $\mathrm{Leu}^{9}-\mathrm{Aph}^{10}-\mathrm{Abu}^{11}$ (Abu: $\alpha$-aminobutyric acid), and $\mathrm{Nva}^{9}-\mathrm{Dmt}^{10}{ }^{-\mathrm{Tr}^{11}}{ }^{11}$ combinations which exhibited $\sim 12$-, 14- and 10-fold increases in $\alpha_{7} \mathrm{nAChR}$ inhibition respectively, when compared with wild type ImI.

Whiteaker et al. (2007) [64] synthesized a highly selective $\alpha_{7} \mathrm{nAChR}$ antagonist by comparing the $\alpha$-conotoxin ArIB (C. arenatus, Figure 6) with other $\alpha$-conotoxin sequences. ArIB blocks both $\alpha_{7}$ and $\alpha_{3} \beta_{2}$ nAChRs, but the authors rationally modified the toxin to increase $\alpha_{7}$ nAChR selectivity. This structure-function analysis yielded two analogs, [V11L,V16A]ArIB and [V11L,V16D]ArIB, which showed low affinity for $\alpha_{3} \beta_{2}$ but retained $\alpha_{7}$ nAChR activity. An iodinated form of [V11L,V16A]ArIB was later developed as a pharmacological tool with the purpose of facilitating the identification of $\alpha_{7}$ nAChRs and enabling the performance of equilibrium binding experiments at $\alpha_{7}$ nAChRs [65].

Recently, Inserra et al. (2013) investigated the importance of $N$-terminal amino acid residues for $\alpha$-conotoxin LsIA (C. limpusi, Figure 6) binding to different nAChRs. Removing the first amino acid (Ser ${ }^{1}$ ) reduced potency at $\alpha_{3} \beta_{2}$ and $\alpha_{7}$ subtypes by 5- and 2-fold, respectively. Moreover, removing the Ser $^{1}$ and Gly ${ }^{2}$ reduced potency by 9 - and 4-fold at $\alpha_{3} \beta_{2}$ and $\alpha_{7}$ nAChRs, respectively. They also suggested the importance of the $C$-terminal chemistry for subtype selectivity [66].

Most $\alpha$-conotoxins are described as antagonists of the nicotinic acetylcholine receptors, though Jin et al. (2013) recently observed that conotoxin MrIC (C. marmoreus, Figure 6) is an almost full agonist at endogenous human $\alpha_{7}$ nAChRs in the presence of PNU, with no activity at endogenous $\alpha_{3} \beta_{2}$ and $\alpha_{3} \beta_{4}$ nAChRs in SH-SY5Y cells. However, it should be noted that this agonist activity could not be confirmed on heterologously expressed $\alpha_{7}$ nAChRs in Xenopus oocytes. On the contrary, MrIC acted as a simple antagonist at human $\alpha_{7}$ nAChRs heterologously expressed in Xenopus oocytes, indicating that significant functional differences of unknown origin exist between neuronal and oocyte expressed $\alpha_{7}$ nAChRs. Understanding the structure-activity and mode of nAChR activation by MrIC may influence the improvement of novel $\alpha_{7} \mathrm{nAChR}$ modulators with potential to treat a range of neurological disorders.

\subsection{2. $\alpha_{3} \beta_{2}$ nAChR Selective $\alpha$-Conotoxins}

The nAChRs including $\alpha_{3}$ subunits $\left(\alpha_{3}{ }^{*}\right)$ are found in autonomic ganglia and modulate cardiovascular functions. The $\alpha_{3}{ }^{*}$ nAChRs expressed by the nociceptive cells in the dorsal root ganglia are likely to modulate pain sensation. In the brain, it is the medial habenula that expresses high $\alpha_{3} *$ nAChR levels [67]. The habenula is involved in anxiety, fear, and the response to stress. The $\alpha_{3} *$ nAChRs present in the medial habenula have gained considerable interest because of their potential role in nicotine addiction. When the cholinergic signaling in the medial habenula of mice was blocked, signs of nicotine withdrawal were noticed [68]. Consequently, up- or down-regulation of $\alpha_{3} * \mathrm{nAChR}$ function may influence the dose of nicotine that rodents will self-administer [69,70]. Therefore, strategies to selectively modulate $\alpha_{3}{ }^{*} \mathrm{nAChR}$ function are of substantial interest. The $\alpha_{3}$ subunit is 
structurally closely related to $\alpha_{6}$. Consequently, conotoxins that distinguish between $\alpha_{3}{ }^{*}$ and $\alpha_{6}{ }^{*}$ nAChRs are rather exceptional.

An $\alpha$-conotoxin of particular interest is MII (C. magus, Figure 8), which potently blocks $\alpha_{3} \beta_{2}$ - and $\alpha_{6}$-containing nAChRs [71]. Harvey et al. (1997) identified specific determinants involved in MII binding on the $\alpha_{3} \beta_{2}$ nAChR. These residues were Lys ${ }^{185}$ and Ile ${ }^{188}$ on $\alpha_{3}$, and $\mathrm{Thr}^{59}, \mathrm{Val}^{109}$, Phe ${ }^{117}$ and Leu ${ }^{119}$ on the $\beta_{2}$ subunit $[18,72]$. With these findings, Dutertre et al. (2005) built an interaction model showing the contribution of the $\beta_{2}$ subunit $[18,72]$.

Figure 8. Sequence alignment of MII, PnIA, PnIB and LvIA. Disulfide bridges are indicated with black lines above the sequences. The first column indicates the different conotoxins discussed in this section, the second column the name of the Conus species and the third column the according amino acid sequence. Loop 1 and loop 2 are labeled below the amino acid sequences. The bold letter in LvIA is an amino acid residue important for $\alpha$-conotoxin interaction as discussed in this section.

\begin{tabular}{|lll|}
\hline MII & c. magus & GCCSNPVCHLEHSNLC \\
PnIA & c. pennaceus & GCCSLPPCAANNPDYC \\
PnIB & c. pennaceus & GCCSLPPCALSNPDYC \\
LVIA & c. lividus & GCCSHPACNVDHPEI, \\
& & Loop 1 Loop 2 \\
\hline
\end{tabular}

As was mentioned in Section 5.1.1., $\alpha$-conotoxin PnIA is a selective antagonist of $\alpha_{3} \beta_{2}$, whereas its related sequence, PnIB, binds preferentially $\alpha_{7}$ nAChRs [55]. Jin et al. (2008) showed that sequential truncation of the second loop influences potency toward $\alpha_{3} \beta_{2}$ and significantly alters the structure of PnIA [73]. Concerning the $\alpha_{3}$ receptor, Everhart et al. (2003) showed that mutating three specific residues on the $\alpha_{3}$ nAChR subunit (Pro ${ }^{182}$, Ile ${ }^{188}$ and Gly ${ }^{198}$ ) affected the high affinity of PnIA [74]. These structure-activity relationship studies resulted in a molecular docking model for interaction between PnIA and the $\alpha_{3} \beta_{2}$ nAChR [45]. This model revealed to be consistent with the subsequent co-crystallization structure of the acetylcholine binding protein (AChBP) and a variant of PnIA [43].

Recently, Luo et al. (2014) discovered the first potent $\alpha_{3} \beta_{2}$-subtype-selective nAChR ligand, named LvIA (C. lividus, Figure 8). Its $\mathrm{IC}_{50}$ value is determined to be $8.67 \mathrm{nM}$ and the amino acid residue $\mathrm{Asp}^{11}$ is believed to play a crucial role in selectivity of LvIA for $\alpha_{3} \beta_{2}$ versus $\alpha_{6} / \alpha_{3} \beta_{2} \beta_{3} \mathrm{nAChR}$ subtypes. They also performed molecular models of the interactions of LvIA with other nAChR subtypes, which suggested that the specificity of LvIA for $\alpha_{3} \beta_{2}$ nAChRs may partly arise from electrostatic interactions between Asp $^{11}$ from LvIA and the receptor. The negatively charged Asp ${ }^{11}$ showed to be buried in a cluster of charged residues, including Asp ${ }^{151}$, Lys ${ }^{154}$ and Glu ${ }^{194}$ of the $\alpha_{3}$ subunit and $\mathrm{Lys}^{78}$ and $\mathrm{Arg}^{80}$ of the $\beta_{2}$ subunit. This cluster of residues forms a globally electropositive environment, which is favorable for an interaction with a negatively charged Asp ${ }^{11}$. Three other nAChR subtypes, i.e., $\alpha_{3} \beta_{4}, \alpha_{6} \beta_{2} \beta_{3}$ and $\alpha_{6} \beta_{4}$, display an equivalent cluster with more negative charges, possibly decreasing the affinity for LvIA. Concerning the $\alpha_{6}$ subunit, position 154 is occupied by a negatively charged Glu residue, whereas the $\alpha_{3}$ subunit has a positively charged Lys residue at this 
position. Concerning the $\beta_{4}$ subunit, position 78 has a neutral Ile residue, whereas the $\beta_{2}$ subunit has a positively charged Lys residue. The decreased binding of $\beta_{4}$ containing subtypes compared to the $\alpha_{3} \beta_{2}$ nAChRs may also be explained by the presence of a salt bridge between Lys ${ }^{58}$ and Glu ${ }^{35}$ of the $\beta_{4}$ subunit which becomes buried when the conotoxin LvIA binds, causing corresponding cost in desolvation energy [75].

\subsection{3. $\alpha_{3} \beta_{4}$ nAChR Selective $\alpha$-Conotoxins}

Because few specific molecular probes toward $\alpha_{3}{ }^{*} \mathrm{nAChRs}$ exist, defining its precise role in normal and pathophysiological conditions is difficult. One particular $\alpha$-conotoxin, AuIB (Figure 9) from C. aulicus, has been frequently studied. However, due to its lower potency $\left(\mathrm{IC}_{50}\right.$ of $\left.750 \mathrm{nM}\right)$, physiological studies are limited.

Figure 9. Sequence alignment of AuIB and TxID. Disulfide bridges are indicated with black lines above the sequences. The first column indicates the different conotoxins discussed in this section, the second column the name of the Conus species and the third column the according amino acid sequence. Loop 1 and loop 2 are labeled below the amino acid sequences. Bold letters are amino acid residues important for $\alpha$-conotoxin interaction as discussed in this section.

\begin{tabular}{|c|c|c|}
\hline AuIB & C.aulicus & GCCSYPPCFATNPDC \\
\hline TXID & C.textile & GCCSHPVCSAMSPIC \\
\hline & & Loop $1 \longdiv { \text { Loop } 2 }$ \\
\hline
\end{tabular}

Alpha-conotoxin AuIB is an $\alpha 4 / 6$-conotoxin and consists of 15 amino acid residues [76]. This peptide is very interesting in several points of view. First, whereas most $\alpha$-conotoxins inhibiting $\alpha_{3} \beta_{4}$ nAChRs, also target $\alpha_{2} \beta_{3}$ nAChR subtypes with similar potency, AuIB exclusively blocks the $\alpha_{3} \beta_{4}$ nAChR subtype. Second, the non-native ribbon disulfide isomer (I-IV, II-III) of AuIB is more potent than the native globular (I-III, II-IV) AuIB disulfide isomer in rat parasympathetic ganglion neurons. This is in contrast with the general assumption that $\alpha$-conotoxins with a different disulfide bond connectivity from the native form typically show losses in biological activity [77]. Third, the native globular AuIB was shown to be a non-competitive $\alpha_{3} \beta_{4}$ antagonist [31], whereas $\alpha$-conotoxins are generally described as competitive nAChR antagonist [78-80]. Remarkably, the AuIB ribbon isomer exhibits subunit stoichiometry-dependent blockade of $\alpha_{3} \beta_{4}$ nAChRs expressed in oocytes, and unlike globular AuIB, it competitively inhibits $\alpha_{3} \beta_{4}$ nAChRs [31].

Grishin and coworkers (2013) [81] recently revealed key amino acid residues that affect AuIB- $\alpha_{3} \beta_{4}$ $\mathrm{nAChR}$ interaction. By performing alanine-scanning mutagenesis and molecular dynamics, they found two alanine-substituted AuIB analogues, [P6A]AuIB and [F9A]AuIB, which did not inhibit $\alpha_{3} \beta_{4}$ nAChRs while [G1A]AuIB only moderately reduced inhibition. Moreover, whereas [F9A]AuIB showed substantially reduced $\alpha_{3} \beta_{4}$ inhibition, also selectivity for other nAChR subtypes shifted. Further investigation of [F9A]AuIB by NMR and circular dichroism (CD) spectroscopy proved that the peptide retained its native globular structure, whereas the [P6A]AuIB analog structure appeared to 
be disrupted. Therefore, activity loss of [F9A]AuIB is supposed to be due to loss of specific toxin-receptor residue pairwise contacts. The authors performed homology modeling of the AuIB- $\alpha_{3} \beta_{4}$ complex which suggested that the $N$-terminus $\mathrm{NH}_{3}{ }^{+}$of AuIB forms a salt bridge with the $\beta_{4} \mathrm{Asp}^{172}$ side chain. The G1A mutation introduces a non-polar $\mathrm{CH}_{3}$ side chain that may weaken this favorable interaction between the peptide $N$-terminus and $\beta_{4} \mathrm{Asp}^{172}$ side chain. Modeling of the other peptides, [P6A]AuIB and [F9A]AuIB, suggested that $\mathrm{Phe}^{9}$ of AuIB interacts with a two-residue binding pocket on the $\beta 4 \mathrm{nAChR}$ subunit. Site-directed mutagenesis of $\beta_{4} \operatorname{Trp}^{59}$ and $\beta_{4} \mathrm{Lys}{ }^{61}$ residues of loop D which form a putative binding pocket, further confirmed this hypothesis. These experiments suggested that Phe $^{9}$ and $\operatorname{Trp}^{59}$ interact via $\pi-\pi$ stacking due to the deep insertion of Phe ${ }^{9}$ in the Trp-Leu-Lys (WLK) pocket. When they removed the positively charged Lys ${ }^{61}$, the inhibition was reduced, which suggested that this residue likely interacts with $\mathrm{Phe}^{9}$ of AuIB and/or stabilizes AuIB-Phe ${ }^{9}$ interaction with $\beta_{4} \operatorname{Trp}^{59}$. All these findings indicated that $\mathrm{Phe}^{9}$ performs a role in the peptide specific interaction with $\alpha_{3} \beta_{4}$ nAChRs and is needed to maintain selectivity for this particular subtype. Interestingly AuIB and several other $\alpha$-conotoxins (such as RgIA and Vc1.1 inhibiting $\alpha_{9} \alpha_{10}$ and $\alpha_{9} \alpha_{10} / \alpha_{7}$, respectively) exhibit analgesic properties when tested in animal models of pain $[13,14]$ (see also Section 5.1.5).

The only other $\alpha 4 / 6$ peptide pharmacologically characterized is $\alpha$-conotoxin TxID (Figure 9), isolated from Conus textile [82]. TxID targets $\alpha_{3} \beta_{4} \mathrm{nAChRs}$ and interestingly it is 60 -fold more potent than AuIB, having an $\mathrm{IC}_{50}$ value of $12.5 \mathrm{nM}$. Nevertheless, TxID also exhibits activity on the closely related $\alpha_{6} / \alpha_{3} \beta_{4}$ nAChR subtype (where $\alpha_{6}$ and $\alpha_{3}$ form a chimeric $\alpha$ subunit) with an $\mathrm{IC}_{50}$ of $94 \mathrm{nM}$. Surface analysis of both peptides revealed that despite their sequence variation, both have a similar type of surface in terms of biophysical properties on one face and a different surface characteristic on the other face. AuIB has a negatively charged Asp residue at position 14, whereas TxID has a hydrophobic Ile residue in the corresponding surface location. As both peptides fold similarly, the authors state that this difference in surface properties might be the reason for higher selectivity of TxID on $\alpha_{3} \beta_{4}$ nAChRs.

TxID has a SHP(V) sequence in the first loop, which is also present in other $\alpha$-conotoxins. This indicates that TxIDs selectivity is probably determined by its unique second loop residues -SAMSPI-. The proline residue in the first loop of TxID is also believed to play a role in the overall conformation as cis-trans isomerism may occur. NMR studies showed that at least two structural isomers are present in TxID.

\subsection{4. $\alpha_{4} \beta_{2}$ nAChR Selective $\alpha$-Conotoxins}

The neuronal nAChRs $\alpha_{4} \beta_{2}$ are the most abundant nicotinic receptors in the human brain. There, they play special roles concerning the efficiency of synaptic communication by modulating the release of other neurotransmitters [83-85]. The $\alpha_{4} \beta_{2}$ nAChRs are found to play a central role in nicotine addiction and in cognitive processes [83-86] which makes them potential targets for drugs designed for improved cognition, smoking cessation, the reduction of pain and a variety of neurological disorders such as Alzheimer's and Parkinson's disease, depression, and attention deficit disorders [87-89].

So far, no conotoxin that selectively targets $\alpha_{4} \beta_{2}$ nAChRs has been identified, and only a few $\alpha$-conotoxins (MII [71], GID [90], GIC [91] and AnIB [92], Figure 10) have been shown to block this receptor, although at high nanomolar or micromolar concentrations. 
Figure 10. Sequence alignment of GID, TxIA, MII, GIC and AnIB. Disulfide bridges are indicated with black lines above the sequences. Dashes are put to make all sequences and intercysteine loops of comparable length. Hydroxyproline residues are indicated as $\mathrm{O}$, $\gamma$-carboxyglutamate residues as $\gamma$. The first column indicates the different conotoxins discussed in this section, the second column the name of the Conus species and the third column the according amino acid sequence. Loop 1 and loop 2 are labeled below the amino acid sequences. Bold letters are amino acid residues important for $\alpha$-conotoxin interaction as discussed in this section.

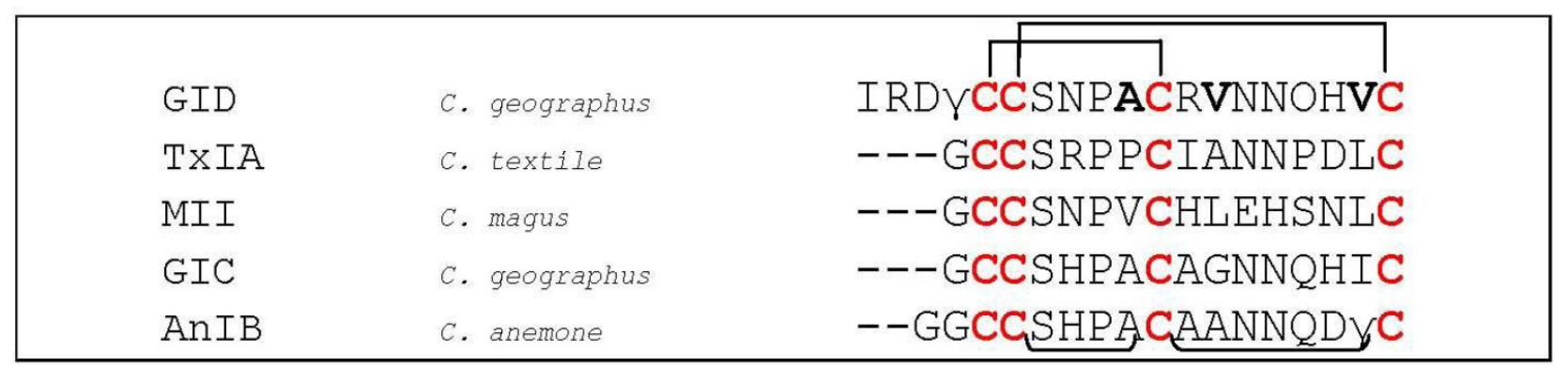

Loop $1 \quad$ Loop 2

The $\alpha$-conotoxin GID (C. geographus, Figure 10) [90], having a relatively high affinity for the $\alpha_{4} \beta_{2}$ nAChR subtype, is unusual because it possesses an extended $N$-terminus of four residues, whereas the $N$-terminal amino acid residue of $\alpha$-conotoxins typically is a glycine followed by the first two cysteine residues. Moreover, two post-translational modifications occur before the mature toxin is completed. An entire alanine scan of all non-cysteine residues revealed that most analogs had at least a 10-fold reduced activity at the $\alpha_{4} \beta_{2}$ subtype, which implies a highly specific interaction of all the amino acids and their charges with the receptor [93]. Recently, Banerjee and colleagues (2014) [94] provided more insight into $\alpha$-conotoxin GID/nAChR interactions by designing the most $\alpha_{4} \beta_{2}$ selective conotoxin analogue identified to date, namely [V18N]GID. The authors observed a potential hydrogen bond interaction between the amide functionality of $\mathrm{Asn}^{18}$ in [V18N]GID and the hydroxyl group of $\mathrm{Y}^{195}$ of $\alpha_{4} \beta_{2}$ nAChRs, but not in the $\alpha_{3} \beta_{2}$ subtype. These interactions appeared to shift the location of the C-loop in the nAChR which might explain the observed selectivity for the $\alpha_{4} \beta_{2}$ nAChR. Two other GID analogues, [A10S]GID and [V13I]GID, demonstrated moderately improved selectivity toward $\alpha_{4} \beta_{2}$ over $\alpha_{3} \beta_{2}$ nAChRs when compared with GID. These observations showed that positions 10, 13 and 18 appear to be major determinants in GID that contribute to selectivity between $\alpha_{4} \beta_{2}$ and $\alpha_{3} \beta_{2}$ nAChRs.

Beissner et al. (2012) [95] investigated several $\alpha$-conotoxins (MII, TxIA and [A10L]TxIA, Figure 10) and found that an arginine residue in position 185 and a proline residue in position 195 of the $\alpha_{4}$ subunit prevent efficient $\alpha$-conotoxin binding. When they replaced these amino acid residues in the $\alpha_{4}$ nicotinic receptor subunit by the corresponding residues in the $\alpha_{3}$ subunit, they could transfer the low nanomolar potency of $\alpha$-conotoxin [A10L]TxIA to the $\alpha_{4} \beta_{2}$ subtype, which is otherwise insensitive to this toxin. They performed docking simulations which revealed an interaction of $\alpha_{4} \operatorname{Arg}^{185}$ with the arginine residue in position 5 of $\alpha$-conotoxin TxIA. The replacement of $\operatorname{Arg}^{185}$ by isoleucine resulted in a 10-fold (MII) up to at least 1000-fold (TxIA and [A10L]TxIA) enhanced 
potency of these $\alpha$-conotoxins at the $\alpha_{4} \beta_{2}$ receptor subtype. Further, they demonstrated that replacement of $\alpha_{4} \mathrm{Arg}^{185}$ by the smaller amino acid Ala or a negatively charged Glu enhanced affinity of the $\alpha_{4} \beta_{2}$ receptor for [A10L]TxIA. On the contrary, a positively charged Lys did not. Hereupon, they concluded that a positive charge in this position specifically prevents high-affinity binding of most conotoxins to the $\alpha_{4} \beta_{2}$ nicotinic receptor and thus represents a major determinant for subtype selectivity.

\subsection{5. $\alpha_{6} *$ nAChR Selective $\alpha$-Conotoxins}

The $\alpha_{6}{ }^{*}$ nAChRs have previously been assumed to be mainly localized to catecholaminergic nuclei of the central nervous system. However, recent data designates that the $\alpha_{6}$ subunit is abundantly expressed in visual pathways and is also present in peripheral tissues [96-98]. The nAChR $\alpha_{6}$ subunit is not widely expressed in the brain, nevertheless it is abundant in midbrain dopaminergic regions which are related to pleasure, reward and mood control [99-102]. Therefore, Yang et al. (2009) suggested that $\alpha_{6} *$ nAChRs might play critical roles in nicotinic reward and in the regulation of mood by nicotine [103]. As mentioned earlier, the $\alpha_{6}$ subunit is structurally closely related to $\alpha_{3}$. Therefore, conotoxins that distinguish between $\alpha_{6} *$ and $\alpha_{3} *$ nAChRs are rather exceptional.

Figure 11. Sequence alignment of MII, PIA, PeIA, BuIA and TxIB. Disulfide bridges are indicated with black lines above the sequences. Dashes are put to make all sequences and intercysteine loops of comparable length. The first column indicates the different conotoxins discussed in this section, the second column the name of the Conus species and the third column the according amino acid sequence. Loop 1 and loop 2 are labeled below the amino acid sequences. Bold letters are amino acid residues important for $\alpha$-conotoxin interaction as discussed in this section.

\begin{tabular}{|c|c|c|}
\hline MII & C. magus & --GCCSNPVCHLEHSNLC \\
\hline PIA & C. purpurascens & RDPCCSNPVCTVHNPQIC \\
\hline PeIA & C. pergrandis & --GCCSHPACSVNHPELC \\
\hline BuIA & C. bullatus & --GCCSTPPCAVLY---C \\
\hline TxIB & C. textile & --GCC $\underbrace{\operatorname{SDPP}} \mathrm{CRNKHPDLC}$ \\
\hline
\end{tabular}

As described in Section 5.1.3, conotoxin MII (C. magus, Figure 11) not only blocks $\alpha_{3} \beta_{2}$ - but also $\alpha_{6}$-containing nAChRs [71]. McIntosh et al. (2004) designed a series of MII analogs selectively targeting the $\alpha_{6} / \alpha_{3} \beta_{2} \beta_{3}$ (where $\alpha_{6}$ and $\alpha_{3}$ form a chimeric $\alpha$ subunit) nAChR combination [104] which were utilized to determine the contribution of $\alpha_{6}$-containing nAChRs in dopamine release in the striatum. The most interesting peptide was [H9A,L15A]MII, which the authors put forward as a selective probe for discriminating among numerous $\mathrm{nAChR}$ subunit combinations, as this MII analog showed low $\mathrm{IC}_{50}$ value for the $\alpha_{6} / \alpha_{3} \beta_{2} \beta_{3} \mathrm{nAChRs}(2.4 \mathrm{nM})$ and a relatively high $\mathrm{IC}_{50}$ for other $\mathrm{nAChRs}$ $\left(\alpha_{2} \beta_{2}, \alpha_{2} \beta_{4}, \alpha_{3} \beta_{2}, \alpha_{3} \beta_{4}, \alpha_{4} \beta_{2}, \alpha_{4} \beta_{4}\right.$ and $\left.\alpha_{7}\right)$. Another analog, [S4A,E11A,L15A]MII, selectively binds the $\alpha_{6}$ versus $\alpha_{3}$ subunit by 1000 -fold. Three residues were determined to be critical for this selectivity, 
namely Glu ${ }^{152}, \mathrm{Asp}^{187}$ and $\mathrm{Thr}^{198}$ [105]. Moreover the down-regulation of $\alpha_{6} / \alpha_{3} \beta_{2} \beta_{3}$ upon long term nicotine exposure could be examined [106,107].

Alpha-conotoxin PIA (C. purpurascens, Figure 11) was the first $\alpha$-conotoxin shown to discriminate between $\alpha_{6}$ versus non- $\alpha_{6}$-containing nAChRs. PIA has namely a 75 -fold lower $\mathrm{IC}_{50}$ for $\alpha_{6} / \alpha_{3} \beta_{2} \beta_{3}$ nAChRs compared to $\alpha_{3} \beta_{2}$ nAChRs. Contrarily, the $\mathrm{IC}_{50}$ for $\alpha_{4} \beta_{2}$ and $\alpha_{2} \beta_{2}$ was more than $10 \mu \mathrm{M}$. The toxin is believed to bind to determinants on the extracellular portion of the $\mathrm{nAChR}$ (i.e., $\alpha_{6}$ ). The remaining $\alpha_{3}$ portion of the chimeric $\alpha_{6} / \alpha_{3}$ subunit does not affect peptide binding. When PIA and MII are compared, both toxins have identical spacing of Cys residues, disulfide connectivity, and the SNPV sequence in the first peptide loop. Therefore, the authors state that differences in either the $N$-terminal or loop 2 sequences account for the differences in selectivity between $\alpha_{6}$ and $\alpha_{3}$ subunits [108].

The $\alpha$-conotoxin PeIA (C. purpurascens, Figure 11) is a peptide antagonist blocking several nAChR subtypes, including $\alpha_{6} / \alpha_{3} \beta_{2} \beta_{3}$ and $\alpha_{6} / \alpha_{3} \beta_{4}$ nAChRs, with low nanomolar potency. Hone et al. (2012) [109] systematically mutated PeIA by substituting specific amino acids of PeIA with those of MII. This resulted in the analog [S9H,V10A,E14N]PeIA which potently blocked $\alpha_{6} / \alpha_{3} \beta_{2} \beta_{3}(223$ pM) and $\alpha_{6} / \alpha_{3} \beta_{4}(65 \mathrm{nM}) \mathrm{nAChRs}$ yielding a $>290$-fold separation between the two subtypes.

Kim and McIntosh (2012) [110] determined a triad of key residues (Lys ${ }^{185}, \mathrm{Thr}^{187}$ and Ile ${ }^{188}$ ) that influence binding of $\alpha$-conotoxin BuIA (Figure 11) from C. bullatus to the $\alpha_{6} \mathrm{nAChR}$ subunit. BuIA blocks $\alpha_{6} / \alpha_{4} \beta_{2} \beta_{3}$ (where $\alpha_{6}$ and $\alpha_{4}$ form a chimeric $\alpha$ subunit) with an $\mathrm{IC}_{50}$ of $0.43 \mathrm{nM}$, whereas it blocks $\alpha_{4} \beta_{2}$ nAChRs with an $\mathrm{IC}_{50}$ of $>20 \mu \mathrm{M}$. When these amino acids were inserted into the $\alpha_{4}$ subunit, there was a 2000-fold increase in toxin potency. Also $\mathrm{Thr}^{198}$ and $\mathrm{Tyr}^{205}$ were shown to contribute to BuIA potency. Moreover, $\mathrm{Thr}^{198}$ caused BuIA potency differences between the closely related $\alpha_{6}$ and $\alpha_{3}$ subunits. $\mathrm{Thr}^{198}$ appears to be a common denominator in $\alpha$-conotoxin subtype discrimination of nAChR $\alpha$-subunits as it was also observed by Azam et al. (2008) [105]. Because $\mathrm{Tyr}^{205}$ is located far from the ligand binding pocket near the boundary with the transmembrane region, the effect on potency by this residue is very likely indirect.

Luo and coworkers (2013) recently reported an $\alpha$-conotoxin, TxIB (C. textile, Figure 11), which selectively targets $\alpha_{6} / \alpha_{3} \beta_{2} \beta_{3}$ nAChRs with an $\mathrm{IC}_{50}$ of $28 \mathrm{nM}$. The toxin has a typical loop 1 Ser-Xaa-Pro motif, but the amino acids "RNKH" in loop 2 are distinct whereupon the authors suggested that the amino acids in loop 2 may be responsible for its selectivity. Other determining factors might be the combination of a smaller hydrophobic patch with flanking positively charged residues of TxIB compared to other conotoxins such as MII, PIA, BuIA, and GIC. As there is a paucity of ligands that can effectively discriminate between $\alpha_{6} \beta_{2}$ and $\alpha_{6} \beta_{4}$ nAChRs, the authors believe that the unique selectivity of TxIB will allow probing of nAChR function in tissues where both the $\alpha_{6}{ }^{*}$ and other nAChR subtypes occur [111].

\subsection{6. $\alpha_{9} \alpha_{10}$ nAChR Selective $\alpha$-Conotoxins}

The $\alpha_{9} \alpha_{10} \mathrm{nAChR}$ subtype, being comprised of two $\alpha_{9}$ and three $\alpha_{10}$ subunits [112], is expressed in outer hair cells mediating efferent olivocochlear innervations and in lymphocytes playing a role in immune responses [113-115]. Moreover, the $\alpha_{9} \alpha_{10} \mathrm{nAChR}$ showed to be involved in immune responses, pain [14,116] and in (breast/lung) cancer therapy, functioning as a molecular target [117]. 
Alpha-conotoxins that target $\alpha_{9} \alpha_{10}$ nAChRs are Vc1.1, RgIA and PeIA [78,118,119] (Figure 12). Synthetic Vc1.1 (ACV1) was initially shown to block potently neuronal $\left(\alpha_{3}, \alpha_{5}, \alpha_{7}\right.$ and $\beta_{4} \mathrm{nAChR}$ subunits) versus muscle nAChRs [11]. Therefore, it was selected for testing in pain models subsequently revealing Vc1.1 as the first $\alpha$-conotoxin exhibiting efficacy in pain models [13,14]. In 2006, Vincler et al. showed that Vc1.1 is a potent antagonist of $\alpha_{9} \alpha_{10}$ nAChRs which potentially contributes to its analgesic effect [12]. Indeed, whereas $\alpha_{9} \alpha_{10}$ nAChR-selective antagonists were demonstrated to relieve pain as well, the mechanism of inactivation of $N$-type calcium channels via $\mathrm{G}$ protein-coupled $\mathrm{GABA}_{\mathrm{B}}$ receptors was thought to be the principal mechanism of analgesic action [120-123]. Later, Napier et al. (2012) determined that Vc1.1 fails to block spinal cord $N$-type calcium channels, raising doubt about this proposed mechanism [124]. Their findings rather suggest that antagonists acting selectively on $\alpha_{3}$ subunit containing nAChRs, but not $\alpha_{4}$ or $\alpha_{9} \alpha_{10}$ subunit-containing nAChRs, may be promising targets in neuropathic pain. ACV1 (Vc1.1) was taken through phase I clinical trials by Metabolic Pharmaceuticals (Melbourne, VIC, Australia), but unfortunately, clinical trials stopped after completion of a phase $2 \mathrm{~A}$ trial because of potential concerns of efficacy and its reduced affinity at human versus rat $\alpha_{9} \alpha_{10}$ nAChRs [5]. Several other $\alpha$-conotoxins (AuIB and RgIA inhibiting $\alpha_{3} \beta_{4}$ and $\alpha_{9} \alpha_{10} \mathrm{nAChRs}$, respectively) also exhibit analgesic properties when tested in animal models of pain $[13,14] . \mathrm{GABA}_{\mathrm{B}}$ receptor-mediated suppression of $N$-type calcium channels $\left(\mathrm{Ca}_{\mathrm{V}} 2.2\right)$ was here too believed to be the common mechanism of analgesic action [125].

Figure 12. Sequence alignment of Vc1.1, RgIA, PeIA and LvIA. Disulfide bridges are indicated with black lines above the sequences. Dashes are put to make all sequences and intercysteine loops of comparable length. The first column indicates the different conotoxins discussed in this section, the second column the name of the Conus species and the third column the according amino acid sequence. Loop 1 and loop 2 are labeled below the amino acid sequences. Bold letters are amino acid residues important for $\alpha$-conotoxin interaction as discussed in this section.

\begin{tabular}{|lll|}
\hline & & \\
VC1.1 & c. victoriae & GCCSDPRCNYDHPEICG \\
PeIA & c. pergrandis & GCCSHPACSVNHPELC- \\
LVIA & c. Iividus & GCCSHPACNVDHPEIC- \\
RgIA & c. regius & GCCSDPRCRYR---_CR \\
& & Loop 1 Loop 2 \\
\hline
\end{tabular}

Halai et al. (2009) [126] performed scanning mutagenesis studies of Vc1.1 (C. victoriae, Figure 12) revealing the residues $\mathrm{Ser}^{4}$ and $\mathrm{Asn}^{9}$ as critical determinants for $\alpha_{9} \alpha_{10} \mathrm{nAChR}$ potency. Mutating Ser ${ }^{4}$ by a more positive residue showed to be more favorable for potency of $\mathrm{Vc1}$.1, whereas mutations to either an Ala or an Asp reduced its activity. If the polar residue $\mathrm{Asn}^{9}$ was replaced by a hydrophobic residue (Ala, Leu or Ile), potency of Vc1.1 significantly increased. A molecular docking study of Vc1.1 combined with electrophysiological recordings performed by Yu et al. (2013) [127] showed that position 9 of $\mathrm{Vc} 1.1$ had most interactions with non-conserved positions of $\mathrm{nAChRs}$. This amino acid is located in the middle of the short $\alpha$-helix of $\mathrm{Vc} 1.1$. Mutational studies revealed that [N9W]Vc1.1 
inhibition of the human $\alpha_{9} \alpha_{10}$ nAChR was significantly increased, whereas the potency of [N9F]Vc1.1 to inhibit this receptor was maintained. All these findings strongly suggested that Vc1.1 and its variants preferentially bind the $\alpha_{10} \alpha_{9}$ binding site and that the formation of a single hydrogen bond between position 59 of the $\alpha_{9}$ subunit and the $C$-terminal amide of Vc1.1 controls specificity between human and rat receptors [127].

The heteropentamer $\alpha_{9} \alpha_{10} \mathrm{nAChR}$ displays three potential binding sites located at the $\alpha_{10} \alpha_{10}, \alpha_{9} \alpha_{10}$, and the $\alpha_{10} \alpha_{9}$ interfaces, where the latter binding site contains more charged residues than the former [127]. Recently, Indurthi et al. (2014) [32] proposed that a fourth possible binding site might exist, i.e., $\alpha_{9} \alpha_{9}$. The $\alpha_{10} \alpha_{9}$ interface was previously set up to be the most probable binding site of Vc1.1, which has four charged side chains [127]. By contrast, PeIA (C. pergrandis, Figure 12) has only one charged side chain, Glu ${ }^{14}$, and potentially binds to the more hydrophobic $\alpha_{9} \alpha_{10}$ pocket. $\alpha$-conotoxin LvIA (C. lividus, Figure 12), a potent antagonist of $\alpha_{3} \beta_{2}$ nAChRs (see Section 5.1.2), retains two charged side chains, $\mathrm{Glu}^{14}$ and Asp ${ }^{11}$, which are believed to be involved in the toxins' inaffinity for the $\alpha_{9} \alpha_{10} \mathrm{nAChR}$. The latter residue is thought to reduce affinity at the $\alpha_{9} \alpha_{10}$ pocket, whereas binding to the $\alpha_{10} \alpha_{9}$ pocket was found to be unlikely due to poor shape complementarity [75].

With regard to RgIA (C. regius, Figure 12), the residues Asp ${ }^{5}, \mathrm{Pro}^{6}$ and $\mathrm{Arg}^{7}$ in loop 1 were shown to be critical for both $\alpha_{9} \alpha_{10}$ and $\alpha_{7} \mathrm{nAChR}$ blockade. By contrast, $\mathrm{Arg}^{9}$ in loop 2 revealed to be crucial for specific binding to the $\alpha_{9} \alpha_{10}$ subtype [128]. In a study from Azam and McIntosh (2012), position 56 of $\alpha_{9} \alpha_{10} \mathrm{nAChRs}$ was determined to control the species selectivity (rat versus human) of $\alpha$-conotoxin RgIA. This toxin is 300 -fold more potent on rat versus human $\alpha_{9} \alpha_{10} \mathrm{nAChRs}$, but it displayed similar activity at the human receptor and at the mutant $r \alpha_{9} \alpha_{10}{ }^{\mathrm{T} 56 \mathrm{I}} \mathrm{nAChR}$ which incorporates the Ile residue present in the human $\alpha_{9}$ subunit. Hereupon, they suggested that RgIA preferentially binds the $\alpha_{10} \alpha_{9}$ pocket, which contains Thr at position 56 of the $\alpha_{9}$ subunit [129].

\subsection{Muscle Subtype $n A C h R s: \alpha_{1} \beta_{1} \delta \varepsilon$ (adult) and $\alpha_{1} \beta_{1} \gamma \delta$ (fetal) $n A C h R s$}

The muscle subtype $\mathrm{nAChRs}, \alpha_{1} \beta_{1} \delta \varepsilon$ (adult) and $\alpha_{1} \beta_{1} \gamma \delta$ (fetal) $\mathrm{nAChRs}$, are found at the neuromuscular junction. During late gestation, the $\gamma$ subunit of the neuromuscular nAChR is replaced by the $\varepsilon$ subunit in mammalian muscle. Nevertheless, also in adult mammalian tissues, instances of fetal muscle nAChR expression exist. Under normal physiological conditions, expression of the $\gamma$ subunit occurs in the thymus [130,131] and extraocular muscle fiber [132]. On the contrary, $\gamma$ subunits are also expressed under pathological conditions such as rhabdomyosarcoma, a pediatric soft-tissue cancer [133-135], in denervated muscle [136,137] and muscle tissue associated with various neurogenic and myogenic disorders.

Structurally, each $\alpha_{1}$ subunit folds such that the principal binding site directly faces a neighboring subunit, which is either a $\gamma / \varepsilon$ or a $\delta$ subunit (Figure 13). The $\gamma$ subunit is believed to be the one that forms stable contacts being the lone subunit between the two $\alpha$ subunits, while the $\delta$ subunit pairs with the $\beta$ subunit to form stable contacts between the $\alpha$ subunits on the opposite side. As two $\alpha_{1}$ subunits are separated by at least one non- $\alpha$ subunit, correct coupling between these subunits is required for cooperative binding of agonists [138]. Agonists of the muscle subtype nAChR initiate channel opening and desensitization by binding to a site on each of these two $\alpha_{1}$ subunits, as well as to the $\gamma /(\varepsilon)$ en $\delta$ subunits [139]. More specific, Arias and Blanton (2000) established that two adjacent cysteines 
(at position 192 and 193 according to the sequence number of Torpedo AChR) in the $\alpha_{1}$ subunits are involved in the recognition and binding of cholinergic agonists and competitive antagonists [140]. Binding of acetylcholine at both binding sites of the muscle nAChRs induces channel activation [141]. Kinetic studies have shown that the two binding sites differ by 30-100 fold in their affinity for acetylcholine [142,143]. Because this compound must occupy both sites to open the channel, it has been suggested that this difference may be physiologically important in priming the receptor for rapid activation (at the high-affinity site) and in abruptly terminating the response to agonists (low-affinity site). Antagonists that act at either binding site will cause a functional block of the receptor [141]. Agonists and antagonists can specifically distinguish between the $\alpha_{1} \gamma /\left(\alpha_{1} \varepsilon\right)$ and $\alpha_{1} \delta$ binding sites of the fetal/(adult) muscle acetylcholine receptor because of different contributions by the $\gamma /(\varepsilon)$ and $\delta$ subunits where a minimum of four loops in both subunits is required to create the agonist binding site [52].

Figure 13. Schematic representation of the fetal muscle subtype nAChR demonstrating (a) the imbedding in the membrane, showing the synaptic space, the cytosol, as well as the M2 $\alpha$ helix and the gate of the nAChR and (b) the acetylcholine binding sites. In both parts, an indication of the size is included. Reproduced from Khalid (2013) [144], with permission from (C) 2013 InTech.

(a)
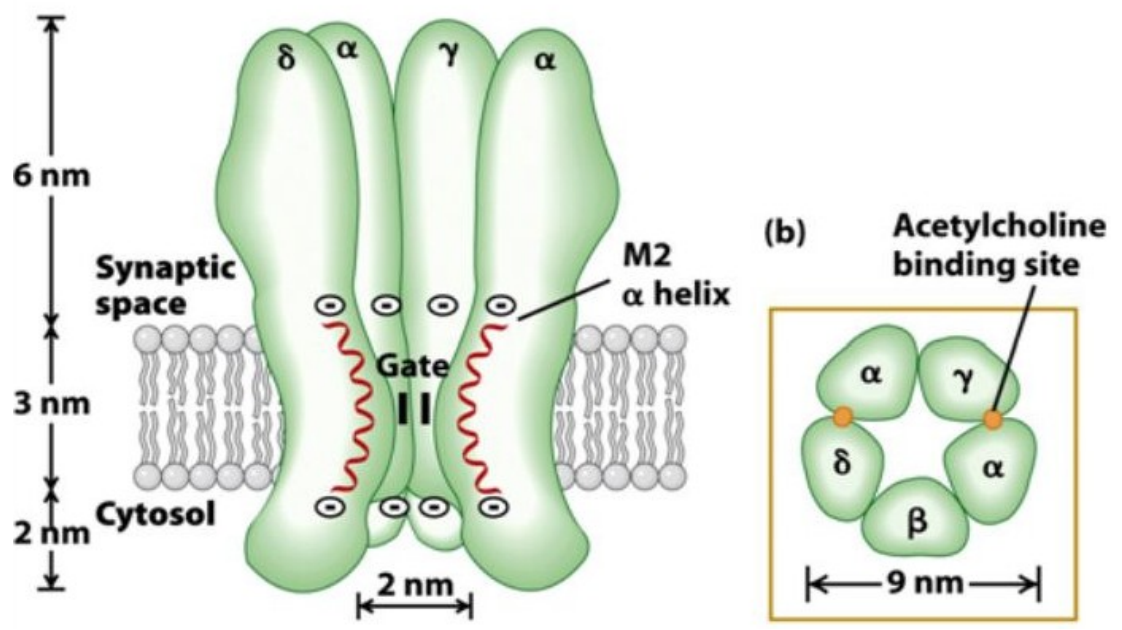

$\alpha$-Conotoxins which selectively target muscle subtype nAChRs typically have a $3 / 5$ structure [5]. The two most investigated $\alpha 3 / 5$ conotoxins are $\alpha$-conotoxin MI (C. magus, Figure 14) and GI (C. geographus, Figure 14). In mammalian muscle nAChRs, both conotoxins showed to preferentially target the $\alpha / \delta$ site by $10^{4}$-fold over the $\alpha / \gamma$ site $[145,146]$. Contrarily, in Torpedo nAChRs, their selectivity profile for each site is opposite, where both conotoxins preferentially bind the acetylcholine binding sites located at the $\alpha / \gamma$ subunit interface versus the $\alpha / \delta$ interface [146-148]. The explanation for this contradiction was later given by Sine et al. (1995). Using chimeric subunits and site-directed mutagenesis, they identified three determinants at equivalent positions of each subunit that direct selectivity of conotoxin MI for the two binding sites. The amino acid residues Lys ${ }^{34}, \mathrm{Ser}^{111}$ and $\mathrm{Phe}^{172}$ of the $\gamma$ subunit were found to be responsible for low affinity to the $\alpha / \gamma$ binding site, whereas the corresponding residues of the $\delta$ subunit, $\mathrm{Ser}^{36}, \mathrm{Tyr}^{113}$ and Ile ${ }^{178}$, conferred high affinity to the $\alpha / \delta$ site. 
The opposite selectivity earlier experienced in Torpedo AChRs was then explained being caused by a Tyr-cation interaction, because in Torpedo, the second determinant is a Tyr in the high affinity $\gamma$ subunit, whereas it is an Arg in the low affinity $\delta$ subunit [149]. Concerning the $\varepsilon$ subunit, residues 106 and 115 of this subunit promote its association with the $\alpha$ subunit, thus affecting efficiency of assembly [150].

Figure 14. Sequence alignment of MII, GI, SrIA, SrIB and EI. Disulfide bridges are indicated with black lines above the sequences. Dashes are put to make all sequences and intercysteine loops of comparable length. Hydroxyproline residues are indicated as $\mathrm{O}$, $\gamma$-carboxyglutamate residues as $\gamma$. The first column indicates the different conotoxins discussed in this section, the second column the name of the Conus species and the third column the according amino acid sequence. Loop 1 and loop 2 are labeled below the amino acid sequences. Bold letters are amino acid residues important for $\alpha$-conotoxin interaction as discussed in this section.

\begin{tabular}{|c|c|c|}
\hline MI & C. magus & -GRCC-HPACGKNYS--C- \\
\hline GI & C. geographus & $--E C C-N P A C G R H Y S--C-$ \\
\hline EI & C. ermineus & RDOCCYHPTCNMSNPQIC- \\
\hline SrIA & C. spurius & -RTCCSROTCRM YYP $Y \mathrm{LCG}$ \\
\hline SrIB & C. spurius & -RTCGSROTGRMEYPYLCG \\
\hline & & Loop 1 \\
\hline
\end{tabular}

A structural binding model of $\alpha$-conotoxin GI (C. geographus, Figure 14) was established by Ghermann et al. [151]. In conotoxin GI, the high differential selectivity and affinity for the two different acetylcholine binding sites of muscle-type nAChRs, located at the $\alpha / \delta$ and $\alpha / \gamma$ subunit interfaces, is mediated by an $\alpha$ subunit binding face and a selectivity face. The former one is made up of $\mathrm{Cys}^{2}, \mathrm{Asn}^{4}, \mathrm{Pro}^{5}, \mathrm{Ala}^{6}$ and $\mathrm{Cys}^{7}[151]$ and the latter one is comprised of $\mathrm{Arg}^{9}$ and $\mathrm{His}^{10}[149,152,153]$. These two faces orient the molecule between the $\alpha$ and $\delta$ subunits of the receptor. Another important residue is $\mathrm{Tyr}^{11}$, shown to be vital for binding. It is believed that this amino acid plays a structural role, i.e., assisting in orienting binding epitopes but not directly binding to the receptor.

The $\alpha 4 / 7$ conotoxin EI (C. ermineus, Figure 14) [154] was the first conotoxin having a 4/7 structure shown to target muscle subtype nAChRs. The toxin selectively binds the $\alpha / \delta$ interface of fetal muscle subtype nAChRs. Other $\alpha 4 / 7$ conotoxins targeting both neuronal $\left(\alpha_{4} \beta_{2}\right)$ and the $\alpha / \delta$ binding site of fetal muscle subtype nAChRs are SrIA and SrIB (C. spurius, Figure 14). The peptides EI and SrIB both have positive net charges which may contribute to their activity on muscle receptors [155]. SrIA and SrIB have a Tyr at position 4 of the second loop, which is also found in most of the $\alpha 3 / 5$ conotoxins blocking $\alpha_{1} \beta_{1} \gamma \delta$ nAChRs. This Tyr was shown to importantly contribute to the binding of the $\alpha_{1} / \delta$ subunit interface of the muscle nAChRs by $\alpha$-conotoxin MI [156]. In the first loop, both peptides of C. spurius have Thr position 4 and a Met at position 2 of the second loop, which may also be involved in muscle nAChR binding [157]. 
Figure 15. Sequence alignment of PrIIIE, PIIIE OIVB and $P_{\text {IVA. Disulfide bridges are }}$ indicated with black lines above the sequences. Dashes are put to make all sequences and intercysteine loops of comparable length. Hydroxyproline residues are indicated as $\mathrm{O}$. The first column indicates the different conotoxins discussed in this section, the second column the name of the Conus species and the third column the according amino acid sequence. Bold letters are amino acid residues important for $\alpha$-conotoxin interaction as discussed in this section.

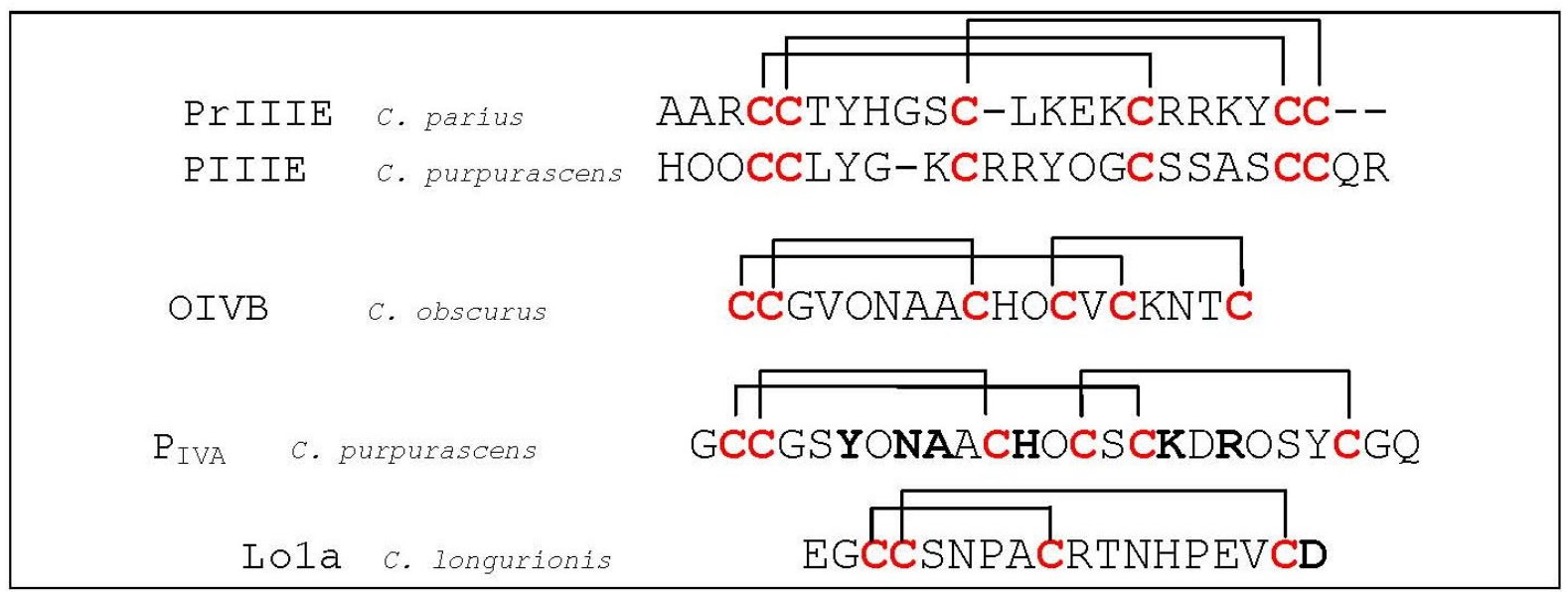

Conotoxins that distinguish between the adult and the fetal muscle subtype nAChRs are generally spoken exceptional. Even rarer are the ones selectively targeting the $\alpha_{1} / \varepsilon$ subunit binding site. One example is $\psi$-conotoxin PrIIIE (C. parius, Figure 15), characterized by Luisma et al. (2008), which shows higher inhibition potency against the adult subtype ( $\mathrm{IC}_{50}$ of $\left.245 \mathrm{nM}\right)$ than the fetal-subtype $\mathrm{nAChR}\left(\mathrm{IC}_{50}\right.$ of $\left.3.24 \mu \mathrm{M}\right)$ [158]. The characteristic disulfide connectivity of $\psi$-conotoxins is typically I-IV; II-V; III-VI compared to I-III; II-IV for $\alpha$-conotoxins. Moreover, $\psi$-conotoxins are usually non-competitive $\mathrm{nAChR}$ antagonists whereas $\alpha$-conotoxins are competitive nAChR antagonists [5]. Another $\psi$-conotoxin PIIIE from (C. purpurascens, Figure 15) shows an $\mathrm{IC}_{50}$ of $7.4 \mu \mathrm{M}$ on the adult muscle subtype, but no inhibition on the fetal muscle subtype for concentrations up to $10 \mu \mathrm{M}$. Although $\psi$-conotoxin PIIIE functionally inhibits the acetylcholine receptor, it does so by a mechanism other than competitive binding to the acetylcholine ligand site [159]. Teichert et al. (2005) reported $\alpha \mathrm{A}$-conotoxin OIVB from C. obscures (Figure 15), a unique selective inhibitor of the mammalian fetal muscle $\mathrm{nAChR}\left(\mathrm{IC}_{50}\right.$ of $56 \mathrm{nM}$ ), whereas affinity for the adult muscle $\mathrm{nAChR}$ is more than 1800 -fold lower suggesting its preference for the $\alpha_{1} / \gamma$ subunit interface [160]. Another $\alpha A$-conotoxin was investigated by Han et al. (1997) [161] who derived the solution structure of [Pro7,13] $\alpha \mathrm{A}$-conotoxin $\mathrm{P}_{\mathrm{IVA}}$ (Figure 15), isolated from C. purpurascens. This competitive nAChR blocker is completely different from the $\alpha$-conotoxins, in that it has three-disulfide bonds with a I-V, II-III, IV-VI connectivity pattern. From their solution structure, the authors proposed a binding core of residues $\mathrm{Tyr}^{6}$, $\mathrm{His}^{12}$ and $\mathrm{Arg}^{19}$, which they superimposed on residues $\mathrm{Arg}^{9}$, $\mathrm{His}^{10}$ and $\mathrm{Tyr}^{11}$ of $\alpha$-conotoxin GI. However, the similar nAChR binding surfaces showed to more likely arise from a combination of the $\mathrm{His}^{12}$ and $\mathrm{Lys}^{17} / \mathrm{Arg}^{19}$ side-chains with possible contributions from $\mathrm{Asn}^{8}$ and $\mathrm{Ala}^{9}$ of $\alpha \mathrm{A}-\mathrm{P}_{\mathrm{IVA}}$ [151]. According to Groebe et al. (1995), many of the $\alpha$-conotoxins bind with 10,000-fold higher affinity to the mammalian $\alpha_{1} / \delta$ interface than the $\alpha_{1} / \gamma$ interface [146]. Recently, Lebbe et al. 
(2014) [162] characterized a particular amino acid residue of $\alpha$-conotoxin Lola (C. longurionis, Figure 15) important for discrimination between neuronal and muscle subtype nicotinic acetylcholine receptors. When the $C$-terminal Asp of Lola, which is insensitive for muscle subtype nAChRs, was deleted or replaced by a positive Arg-tail, they observed an adaptation of affinity for the adult muscle subtype $\alpha_{1} \beta_{1} \delta \varepsilon$. IC $\mathrm{IC}_{50}$ values were as follows: $>50 \mu \mathrm{M}$ (Lo1a), $4.40 \mu \mathrm{M}$ (Lo1a- $\left.\Delta \mathrm{D}\right)$ and $1.47 \mu \mathrm{M}$ (Lola-RRR).

\section{Conclusions}

This review aims to give an overview of the molecular pharmacology of $\alpha$-conotoxins that selectively interact with nicotinic acetylcholine receptors. The diverse composition of nAChRs is implicated in the pathophysiology of a number of diseases including epilepsy, schizophrenia, Alzheimer's disease, Parkinson's disease, nicotine addiction, etc. Although a lot of effort has already been done which resulted in the indication of crucial determinants for activity on particular nAChRs, a lot of questions still remain. These question marks include on the one hand some mechanisms of actions that are often controversial or still remain to be elucidated and on the other hand the lack of structure-activity data for $\alpha$-conotoxins selectively targeting $\alpha_{2}$ nAChRs. The importance of the characterization of these activity-relationship interactions cannot be neglected, as is illustrated by the number of diseases which are involved. Therefore, enormous challenges are facing future research, but we are hopeful that this will be rewarded, providing a scaffold for selective peptide-engineering which can be used in drug discovery and consequently, disease treatment.

\section{Acknowledgments}

This work was supported by the following grants: G.0433.12, G.A071.10N and G.0257.08 (F.W.O. Vlaanderen), EU-FP7-MAREX, IUAP 7/10 (Inter-University Attraction Poles Program, Belgian State, Belgian Science Policy), F+/12/036 and OT/12/081 (KU Leuven).

\section{Conflicts of Interest}

The authors declare no conflict of interest.

\section{References}

1. Fry, B.G.; Roelants, K.; Champagne, D.E.; Scheib, H.; Tyndall, J.D.; King, G.F.; Nevalainen, T.J.; Norman, J.A.; Lewis, R.J.; Norton, R.S.; et al. The toxicogenomic multiverse: Convergent recruitment of proteins into animal venoms. Annu. Rev. Genomics Hum. Genet. 2009, 10, 483-511.

2. Milne, T.J.; Abbenante, G.; Tyndall, J.D.; Halliday, J.; Lewis, R.J. Isolation and characterization of a cone snail protease with homology to CRISP proteins of the pathogenesis-related protein superfamily. J. Biol. Chem. 2003, 278, 31105-31110.

3. Davis, J.; Jones, A.; Lewis, R.J. Remarkable inter- and intra-species complexity of conotoxins revealed by LC/MS. Peptides 2009, 30, 1222-1227. 
4. Olivera, B.M.; Rivier, J.; Clark, C.; Ramilo, C.A.; Corpuz, G.P.; Abogadie, F.C.; Mena, E.E.; Woodward, S.R.; Hillyard, D.R.; Cruz, L.J. Diversity of Conus neuropeptides. Science 1990, 249, 257-263.

5. Lewis, R.J.; Dutertre, S.; Vetter, I.; Christie, M.J. Conus venom peptide pharmacology. Pharmacol. Rev. 2012, 64, 259-298.

6. McIntosh, J.M.; Santos, A.D.; Olivera, B.M. Conus peptides targeted to specific nicotinic acetylcholine receptor subtypes. Annu. Rev. Biochem. 1999, 68, 59-88.

7. Dutertre, S.; Ulens, C.; Buttner, R.; Fish, A.; van Elk, R.; Kendel, Y.; Hopping, G.; Alewood, P.F.; Schroeder, C.; Nicke, A.; et al. AChBP-targeted alpha-conotoxin correlates distinct binding orientations with nAChR subtype selectivity. EMBO J. 2007, 26, 3858-3867.

8. McIntosh, J.M.; Yoshikami, D.; Mahe, E.; Nielsen, D.B.; Rivier, J.E.; Gray, W.R.; Olivera, B.M. A nicotinic acetylcholine receptor ligand of unique specificity, alpha-conotoxin ImI. J. Biol. Chem. 1994, 269, 16733-16739.

9. Terlau, H.; Olivera, B.M. Conus venoms: A rich source of novel ion channel-targeted peptides. Physiol. Rev. 2004, 84, 41-68.

10. Janes, R.W. alpha-Conotoxins as selective probes for nicotinic acetylcholine receptor subclasses. Curr. Opin. Pharmacol. 2005, 5, 280-292.

11. Livett, B.G.; Sandall, D.W.; Keays, D.; Down, J.; Gayler, K.R.; Satkunanathan, N.; Khalil, Z. Therapeutic applications of conotoxins that target the neuronal nicotinic acetylcholine receptor. Toxicon 2006, 48, 810-829.

12. Vincler, M.; Wittenauer, S.; Parker, R.; Ellison, M.; Olivera, B.M.; McIntosh, J.M. Molecular mechanism for analgesia involving specific antagonism of alpha9alpha10 nicotinic acetylcholine receptors. Proc. Natl. Acad. Sci. USA 2006, 103, 17880-17884.

13. Sandall, D.W.; Satkunanathan, N.; Keays, D.A.; Polidano, M.A.; Liping, X.; Pham, V.; Down, J.G.; Khalil, Z.; Livett, B.G.; Gayler, K.R. A novel alpha-conotoxin identified by gene sequencing is active in suppressing the vascular response to selective stimulation of sensory nerves in vivo. Biochemistry 2003, 42, 6904-6911.

14. Satkunanathan, N.; Livett, B.; Gayler, K.; Sandall, D.; Down, J.; Khalil, Z. Alpha-conotoxin Vc1.1 alleviates neuropathic pain and accelerates functional recovery of injured neurones. Brain Res. 2005, 1059, 149-158.

15. PyMOL version 1.3. Available online: http://pymol.sourceforge.net/ (accessed on 10 April 2013).

16. Yuan, D.D.; Han, Y.H.; Wang, C.G.; Chi, C.W. From the identification of gene organization of alpha conotoxins to the cloning of novel toxins. Toxicon 2007, 49, 1135-1149.

17. Olivera, B.M.E.E. Just Lecture, 1996. Conus venom peptides, receptor and ion channel targets, and drug design: 50 million years of neuropharmacology. Mol. Biol. Cell 1997, 8, 2101-2109.

18. Dutertre, S.; Nicke, A.; Lewis, R.J. Beta2 subunit contribution to 4/7 alpha-conotoxin binding to the nicotinic acetylcholine receptor. J. Biol. Chem. 2005, 280, 30460-30468.

19. Miller, P.S.; Smart, T.G. Binding, activation and modulation of Cys-loop receptors. Trends Pharmacol. Sci. 2010, 31, 161-174.

20. Dellisanti, C.D.; Ghosh, B.; Hanson, S.M.; Raspanti, J.M.; Grant, V.A.; Diarra, G.M.; Schuh, A.M.; Satyshur, K.; Klug, C.S.; Czajkowski, C. Site-directed spin labeling reveals pentameric ligand-gated ion channel gating motions. PLoS Biol. 2013, 11, e1001714. 
21. Gotti, C.; Clementi, F. Neuronal nicotinic receptors: From structure to pathology. Prog. Neurobiol. 2004, 74, 363-396.

22. Klee, E.W.; Ebbert, J.O.; Schneider, H.; Hurt, R.D.; Ekker, S.C. Zebrafish for the study of the biological effects of nicotine. Nicotine Tob. Res. 2011, 13, 301-312.

23. Tapper, A.R.; McKinney, S.L.; Nashmi, R.; Schwarz, J.; Deshpande, P.; Labarca, C.; Whiteaker, P.; Marks, M.J.; Collins, A.C.; Lester, H.A. Nicotine activation of alpha4* receptors: Sufficient for reward, tolerance, and sensitization. Science 2004, 306, 1029-1032.

24. Improgo, M.R.; Scofield, M.D.; Tapper, A.R.; Gardner, P.D. The nicotinic acetylcholine receptor CHRNA5/A3/B4 gene cluster: Dual role in nicotine addiction and lung cancer. Prog. Neurobiol. 2010, 92, 212-226.

25. Hurst, R.; Rollema, H.; Bertrand, D. Nicotinic acetylcholine receptors: From basic science to therapeutics. Pharmacol. Ther. 2013, 137, 22-54.

26. Albuquerque, E.X.; Pereira, E.F.; Alkondon, M.; Rogers, S.W. Mammalian nicotinic acetylcholine receptors: From structure to function. Physiol. Rev. 2009, 89, 73-120.

27. Papke, R.L.; Thinschmidt, J.S.; Moulton, B.A.; Meyer, E.M.; Poirier, A. Activation and inhibition of rat neuronal nicotinic receptors by ABT-418. Br. J. Pharmacol. 1997, 120, 429-438.

28. Carson, K.V.; Brinn, M.P.; Robertson, T.A.; To, A.N.R.; Esterman, A.J.; Peters, M.; Smith, B.J. Current and emerging pharmacotherapeutic options for smoking cessation. Subst. Abuse 2013, 7, 85-105.

29. Rahman, S. Nicotinic receptors as therapeutic targets for drug addictive disorders. CNS Neurol Disord. Drug Targets 2013, 12, 633-640.

30. Colovic, M.B.; Krstic, D.Z.; Lazarevic-Pasti, T.D.; Bondzic, A.M.; Vasic, V.M. Acetylcholinesterase inhibitors: Pharmacology and toxicology. Curr. Neuropharmacol. 2013, 11, 315-335.

31. Grishin, A.A.; Wang, C.I.; Muttenthaler, M.; Alewood, P.F.; Lewis, R.J.; Adams, D.J. Alpha-conotoxin AuIB isomers exhibit distinct inhibitory mechanisms and differential sensitivity to stoichiometry of alpha3beta4 nicotinic acetylcholine receptors. J. Biol. Chem. 2010, 285, 22254-22263.

32. Indurthi, D.C.; Pera, E.; Kim, H.L.; Chu, C.; McLeod, M.D.; Michael McIntosh, J.; Absalom, N.L.; Chebib, M. Presence of multiple binding sites on alpha9alpha10 nAChR receptors alludes to stoichiometric dependent action of the alpha-conotoxin, Vc1.1. Biochem. Pharmacol. 2014, 98, 131-140.

33. Kabbani, N.; Nordman, J.C.; Corgiat, B.A.; Veltri, D.P.; Shehu, A.; Seymour, V.A.; Adams, D.J. Are nicotinic acetylcholine receptors coupled to G proteins? BioEssays 2013, 35, 1025-1034.

34. Unwin, N. Refined structure of the nicotinic acetylcholine receptor at 4A resolution. J. Mol. Biol. 2005, 346, 967-989.

35. Unwin, N.; Fujiyoshi, Y. Gating movement of acetylcholine receptor caught by plunge-freezing. J. Mol. Biol. 2012, 422, 617-634.

36. Brejc, K.; van Dijk, W.J.; Klaassen, R.V.; Schuurmans, M.; van Der Oost, J.; Smit, A.B.; Sixma, T.K. Crystal structure of an ACh-binding protein reveals the ligand-binding domain of nicotinic receptors. Nature 2001, 411, 269-276. 
37. Armishaw, C.; Jensen, A.A.; Balle, T.; Clark, R.J.; Harpsoe, K.; Skonberg, C.; Liljefors, T.; Stromgaard, K. Rational design of alpha-conotoxin analogues targeting alpha7 nicotinic acetylcholine receptors: Improved antagonistic activity by incorporation of proline derivatives. J. Biol. Chem. 2009, 284, 9498-9512.

38. Celie, P.H.; van Rossum-Fikkert, S.E.; van Dijk, W.J.; Brejc, K.; Smit, A.B.; Sixma, T.K. Nicotine and carbamylcholine binding to nicotinic acetylcholine receptors as studied in AChBP crystal structures. Neuron 2004, 41, 907-914.

39. Celie, P.H.; Klaassen, R.V.; van Rossum-Fikkert, S.E.; van Elk, R.; van Nierop, P.; Smit, A.B.; Sixma, T.K. Crystal structure of acetylcholine-binding protein from Bulinus truncatus reveals the conserved structural scaffold and sites of variation in nicotinic acetylcholine receptors. J. Biol. Chem. 2005, 280, 26457-26466.

40. Dellisanti, C.D.; Yao, Y.; Stroud, J.C.; Wang, Z.Z.; Chen, L. Crystal structure of the extracellular domain of nAChR alphal bound to alpha-bungarotoxin at 1.94 A resolution. Nat. Neurosci. 2007, 10, 953-962.

41. Li, S.X.; Huang, S.; Bren, N.; Noridomi, K.; Dellisanti, C.D.; Sine, S.M.; Chen, L. Ligand-binding domain of an alpha7-nicotinic receptor chimera and its complex with agonist. Nat. Neurosci. 2011, 14, 1253-1259.

42. Ulens, C.; Hogg, R.C.; Celie, P.H.; Bertrand, D.; Tsetlin, V.; Smit, A.B.; Sixma, T.K. Structural determinants of selective alpha-conotoxin binding to a nicotinic acetylcholine receptor homolog AChBP. Proc. Natl. Acad. Sci. USA 2006, 103, 3615-3620.

43. Celie, P.H.; Kasheverov, I.E.; Mordvintsev, D.Y.; Hogg, R.C.; van Nierop, P.; van Elk, R.; van Rossum-Fikkert, S.E.; Zhmak, M.N.; Bertrand, D.; Tsetlin, V.; et al. Crystal structure of nicotinic acetylcholine receptor homolog AChBP in complex with an alpha-conotoxin PnIA variant. Nat. Struct. Mol. Biol. 2005, 12, 582-588.

44. Harel, M.; Kasher, R.; Nicolas, A.; Guss, J.M.; Balass, M.; Fridkin, M.; Smit, A.B.; Brejc, K.; Sixma, T.K.; Katchalski-Katzir, E.; et al. The binding site of acetylcholine receptor as visualized in the X-Ray structure of a complex between alpha-bungarotoxin and a mimotope peptide. Neuron 2001, 32, 265-275.

45. Dutertre, S.; Nicke, A.; Tyndall, J.D.; Lewis, R.J. Determination of alpha-conotoxin binding modes on neuronal nicotinic acetylcholine receptors. J. Mol. Recognit. 2004, 17, 339-347.

46. Couturier, S.; Bertrand, D.; Matter, J.M.; Hernandez, M.C.; Bertrand, S.; Millar, N.; Valera, S.; Barkas, T.; Ballivet, M. A neuronal nicotinic acetylcholine receptor subunit (alpha 7) is developmentally regulated and forms a homo-oligomeric channel blocked by alpha-BTX. Neuron 1990, 5, 847-856.

47. Rubboli, F.; Court, J.A.; Sala, C.; Morris, C.; Chini, B.; Perry, E.; Clementi, F. Distribution of nicotinic receptors in the human hippocampus and thalamus. Eur. J. Neurosci. 1994, 6, 1596-1604.

48. Wevers, A.; Jeske, A.; Lobron, C.; Birtsch, C.; Heinemann, S.; Maelicke, A.; Schroder, R.; Schroder, H. Cellular distribution of nicotinic acetylcholine receptor subunit mRNAs in the human cerebral cortex as revealed by non-isotopic in situ hybridization. Brain Res. Mol. Brain Res. 1994, 25, 122-128. 
49. Breese, C.R.; Adams, C.; Logel, J.; Drebing, C.; Rollins, Y.; Barnhart, M.; Sullivan, B.; Demasters, B.K.; Freedman, R.; Leonard, S. Comparison of the regional expression of nicotinic acetylcholine receptor alpha7 mRNA and [125I]-alpha-bungarotoxin binding in human postmortem brain. J. Comp. Neurol 1997, 387, 385-398.

50. Sacco, K.A.; Bannon, K.L.; George, T.P. Nicotinic receptor mechanisms and cognition in normal states and neuropsychiatric disorders. J. Psychopharmacol. 2004, 18, 457-474.

51. Steinlein, O.K.; Bertrand, D. Nicotinic receptor channelopathies and epilepsy. Pflugers Arch. 2010, 460, 495-503.

52. Prince, R.J.; Sine, S.M. Molecular dissection of subunit interfaces in the acetylcholine receptor. Identification of residues that determine agonist selectivity. J. Biol. Chem. 1996, 271, 25770-25777.

53. Dutertre, S.; Lewis, R.J. Computational approaches to understand alpha-conotoxin interactions at neuronal nicotinic receptors. Eur. J. Biochem. 2004, 271, 2327-2334.

54. Taly, A.; Corringer, P.J.; Grutter, T.; Prado de Carvalho, L.; Karplus, M.; Changeux, J.P. Implications of the quaternary twist allosteric model for the physiology and pathology of nicotinic acetylcholine receptors. Proc. Natl. Acad. Sci. USA 2006, 103, 16965-16970.

55. Fainzilber, M.; Hasson, A.; Oren, R.; Burlingame, A.L.; Gordon, D.; Spira, M.E.; Zlotkin, E. New mollusc-specific alpha-conotoxins block Aplysia neuronal acetylcholine receptors. Biochemistry 1994, 33, 9523-9529.

56. Hogg, R.C.; Miranda, L.P.; Craik, D.J.; Lewis, R.J.; Alewood, P.F.; Adams, D.J. Single amino acid substitutions in alpha-conotoxin PnIA shift selectivity for subtypes of the mammalian neuronal nicotinic acetylcholine receptor. J. Biol. Chem. 1999, 274, 36559-36564.

57. Luo, S.; Nguyen, T.A.; Cartier, G.E.; Olivera, B.M.; Yoshikami, D.; McIntosh, J.M. Single-residue alteration in alpha-conotoxin PnIA switches its nAChR subtype selectivity. Biochemistry 1999, 38, 14542-14548.

58. Hogg, R.C.; Hopping, G.; Alewood, P.F.; Adams, D.J.; Bertrand, D. Alpha-conotoxins PnIA and [A10L]PnIA stabilize different states of the alpha7-L247T nicotinic acetylcholine receptor. J. Biol. Chem. 2003, 278, 26908-26914.

59. Quiram, P.A.; McIntosh, J.M.; Sine, S.M. Pairwise interactions between neuronal alpha(7) acetylcholine receptors and alpha-conotoxin PnIB. J. Biol. Chem. 2000, 275, 4889-4896.

60. Quiram, P.A.; Sine, S.M. Structural elements in alpha-conotoxin ImI essential for binding to neuronal alpha7 receptors. J. Biol. Chem. 1998, 273, 11007-11011.

61. Quiram, P.A.; Sine, S.M. Identification of residues in the neuronal alpha7 acetylcholine receptor that confer selectivity for conotoxin ImI. J. Biol. Chem. 1998, 273, 11001-11006.

62. Quiram, P.A.; Jones, J.J.; Sine, S.M. Pairwise interactions between neuronal alpha7 acetylcholine receptors and alpha-conotoxin ImI. J. Biol. Chem. 1999, 274, 19517-19524.

63. Hansen, S.B.; Sulzenbacher, G.; Huxford, T.; Marchot, P.; Taylor, P.; Bourne, Y. Structures of Aplysia AChBP complexes with nicotinic agonists and antagonists reveal distinctive binding interfaces and conformations. EMBO J. 2005, 24, 3635-3646.

64. Whiteaker, P.; Christensen, S.; Yoshikami, D.; Dowell, C.; Watkins, M.; Gulyas, J.; Rivier, J.; Olivera, B.M.; McIntosh, J.M. Discovery, synthesis, and structure activity of a highly selective alpha7 nicotinic acetylcholine receptor antagonist. Biochemistry 2007, 46, 6628-6638. 
65. Whiteaker, P.; Marks, M.J.; Christensen, S.; Dowell, C.; Collins, A.C.; McIntosh, J.M. Synthesis and characterization of 125I-alpha-conotoxin ArIB[V11L;V16A], a selective alpha7 nicotinic acetylcholine receptor antagonist. J. Pharmacol. Exp. Ther. 2008, 325, 910-919.

66. Inserra, M.C.; Kompella, S.N.; Vetter, I.; Brust, A.; Daly, N.L.; Cuny, H.; Craik, D.J.; Alewood, P.F.; Adams, D.J.; Lewis, R.J. Isolation and characterization of alpha-conotoxin LsIA with potent activity at nicotinic acetylcholine receptors. Biochem. Pharmacol. 2013, 86, 791-799.

67. Marks, M.J.; Smith, K.W.; Collins, A.C. Differential agonist inhibition identifies multiple epibatidine binding sites in mouse brain. J. Pharmacol. Exp. Ther. 1998, 285, 377-386.

68. Salas, R.; Sturm, R.; Boulter, J.; de Biasi, M. Nicotinic receptors in the habenulo-interpeduncular system are necessary for nicotine withdrawal in mice. J. Neurosci. 2009, 29, 3014-3018.

69. Fowler, C.D.; Lu, Q.; Johnson, P.M.; Marks, M.J.; Kenny, P.J. Habenular alpha5 nicotinic receptor subunit signalling controls nicotine intake. Nature 2011, 471, 597-601.

70. Paolini, M.; de Biasi, M. Mechanistic insights into nicotine withdrawal. Biochem. Pharmacol. 2011, 82, 996-1007.

71. Cartier, G.E.; Yoshikami, D.; Gray, W.R.; Luo, S.; Olivera, B.M.; McIntosh, J.M. A new alpha-conotoxin which targets alpha3beta2 nicotinic acetylcholine receptors. J. Biol. Chem. 1996, 271, 7522-7528.

72. Harvey, S.C.; McIntosh, J.M.; Cartier, G.E.; Maddox, F.N.; Luetje, C.W. Determinants of specificity for alpha-conotoxin MII on alpha3beta2 neuronal nicotinic receptors. Mol. Pharmacol. 1997, 51, 336-342.

73. Jin, A.H.; Daly, N.L.; Nevin, S.T.; Wang, C.I.; Dutertre, S.; Lewis, R.J.; Adams, D.J.; Craik, D.J.; Alewood, P.F. Molecular engineering of conotoxins: The importance of loop size to alpha-conotoxin structure and function. J. Med. Chem. 2008, 51, 5575-5584.

74. Everhart, D.; Reiller, E.; Mirzoian, A.; McIntosh, J.M.; Malhotra, A.; Luetje, C.W. Identification of residues that confer alpha-conotoxin-PnIA sensitivity on the alpha 3 subunit of neuronal nicotinic acetylcholine receptors. J. Pharmacol. Exp. Ther. 2003, 306, 664-670.

75. Luo, S.; Zhangsun, D.; Schroeder, C.I.; Zhu, X.; Hu, Y.; Wu, Y.; Weltzin, M.M.; Eberhard, S.; Kaas, Q.; Craik, D.J.; et al. A novel alpha4/7-conotoxin LvIA from Conus lividus that selectively blocks alpha3beta2 vs. alpha6/alpha3beta2beta3 nicotinic acetylcholine receptors. FASEB J. 2014, 28, 1842-1853.

76. Luo, S.; Kulak, J.M.; Cartier, G.E.; Jacobsen, R.B.; Yoshikami, D.; Olivera, B.M.; McIntosh, J.M. alpha-conotoxin AuIB selectively blocks alpha3 beta4 nicotinic acetylcholine receptors and nicotine-evoked norepinephrine release. J. Neurosci. 1998, 18, 8571-8579.

77. Dutton, J.L.; Bansal, P.S.; Hogg, R.C.; Adams, D.J.; Alewood, P.F.; Craik, D.J. A new level of conotoxin diversity, a non-native disulfide bond connectivity in alpha-conotoxin AuIB reduces structural definition but increases biological activity. J. Biol. Chem. 2002, 277, 48849-48857.

78. Clark, R.J.; Fischer, H.; Nevin, S.T.; Adams, D.J.; Craik, D.J. The synthesis, structural characterization, and receptor specificity of the alpha-conotoxin Vc1.1. J. Biol. Chem. 2006, 281, 23254-23263. 
79. Innocent, N.; Livingstone, P.D.; Hone, A.; Kimura, A.; Young, T.; Whiteaker, P.; McIntosh, J.M.; Wonnacott, S. Alpha-conotoxin Arenatus IB[V11L,V16D] [corrected] is a potent and selective antagonist at rat and human native alpha7 nicotinic acetylcholine receptors. J. Pharmacol. Exp. Ther. 2008, 327, 529-537.

80. Pereira, E.F.; Alkondon, M.; McIntosh, J.M.; Albuquerque, E.X. Alpha-conotoxin-ImI: A competitive antagonist at alpha-bungarotoxin-sensitive neuronal nicotinic receptors in hippocampal neurons. J. Pharmacol. Exp. Ther. 1996, 278, 1472-1483.

81. Grishin, A.A.; Cuny, H.; Hung, A.; Clark, R.J.; Brust, A.; Akondi, K.; Alewood, P.F.; Craik, D.J.; Adams, D.J. Identifying key amino acid residues that affect alpha-conotoxin AuIB inhibition of alpha3beta4 nicotinic acetylcholine receptors. J. Biol. Chem. 2013, 288, 34428-34442.

82. Luo, S.; Zhangsun, D.; Zhu, X.; Wu, Y.; Hu, Y.; Christensen, S.; Harvey, P.J.; Akcan, M.; Craik, D.J.; McIntosh, J.M. Characterization of a Novel alpha-Conotoxin TxID from Conus textile That Potently Blocks Rat alpha3beta4 Nicotinic Acetylcholine Receptors. J. Med. Chem. 2013, 56, 9655-9663.

83. Gotti, C.; Zoli, M.; Clementi, F. Brain nicotinic acetylcholine receptors: Native subtypes and their relevance. Trends Pharmacol. Sci. 2006, 27, 482-491.

84. Wonnacott, S. Presynaptic nicotinic ACh receptors. Trends Neurosci. 1997, 20, 92-98.

85. Grady, S.R.; Salminen, O.; McIntosh, J.M.; Marks, M.J.; Collins, A.C. Mouse striatal dopamine nerve terminals express alpha4alpha5beta2 and two stoichiometric forms of alpha4beta2*-nicotinic acetylcholine receptors. J. Mol. Neurosci. 2010, 40, 91-95.

86. Flores, C.M.; Rogers, S.W.; Pabreza, L.A.; Wolfe, B.B.; Kellar, K.J. A subtype of nicotinic cholinergic receptor in rat brain is composed of alpha 4 and beta 2 subunits and is up-regulated by chronic nicotine treatment. Mol. Pharmacol. 1992, 41, 31-37.

87. Rueter, L.E.; Donnelly-Roberts, D.L.; Curzon, P.; Briggs, C.A.; Anderson, D.J.; Bitner, R.S. A-85380: A pharmacological probe for the preclinical and clinical investigation of the alphabeta neuronal nicotinic acetylcholine receptor. CNS Drug Rev. 2006, 12, 100-112.

88. Ebbert, J.O. Emerging drugs for the treatment of tobacco dependence. Expert Opin. Emerg. Drugs 2009, 14, 23-32.

89. Taly, A.; Corringer, P.J.; Guedin, D.; Lestage, P.; Changeux, J.P. Nicotinic receptors: Allosteric transitions and therapeutic targets in the nervous system. Nat. Rev. Drug Discov. 2009, 8, 733-750.

90. Nicke, A.; Loughnan, M.L.; Millard, E.L.; Alewood, P.F.; Adams, D.J.; Daly, N.L.; Craik, D.J.; Lewis, R.J. Isolation, structure, and activity of GID, a novel alpha 4/7-conotoxin with an extended $N$-terminal sequence. J. Biol. Chem. 2003, 278, 3137-3144.

91. McIntosh, J.M.; Dowell, C.; Watkins, M.; Garrett, J.E.; Yoshikami, D.; Olivera, B.M. Alpha-conotoxin GIC from Conus geographus, a novel peptide antagonist of nicotinic acetylcholine receptors. J. Biol. Chem. 2002, 277, 33610-33615.

92. Loughnan, M.L.; Nicke, A.; Jones, A.; Adams, D.J.; Alewood, P.F.; Lewis, R.J. Chemical and functional identification and characterization of novel sulfated alpha-conotoxins from the cone snail Conus anemone. J. Med. Chem. 2004, 47, 1234-1241. 
93. Millard, E.L.; Nevin, S.T.; Loughnan, M.L.; Nicke, A.; Clark, R.J.; Alewood, P.F.; Lewis, R.J.; Adams, D.J.; Craik, D.J.; Daly, N.L. Inhibition of neuronal nicotinic acetylcholine receptor subtypes by alpha-Conotoxin GID and analogues. J. Biol. Chem. 2009, 284, 4944-4951.

94. Banerjee, J.; Yongye, A.B.; Chang, Y.P.; Gyanda, R.; Medina-Franco, J.L.; Armishaw, C.J. Design and synthesis of alpha-conotoxin GID analogues as selective alpha4beta2 nicotinic acetylcholine receptor antagonists. Biopolymers 2014, 102, 78-87.

95. Beissner, M.; Dutertre, S.; Schemm, R.; Danker, T.; Sporning, A.; Grubmuller, H.; Nicke, A. Efficient binding of 4/7 alpha-conotoxins to nicotinic alpha4beta2 receptors is prevented by Arg185 and Pro195 in the alpha4 subunit. Mol. Pharmacol. 2012, 82, 711-718.

96. Mackey, E.D.; Engle, S.E.; Kim, M.R.; O’Neill, H.C.; Wageman, C.R.; Patzlaff, N.E.; Wang, Y.; Grady, S.R.; McIntosh, J.M.; Marks, M.J.; et al. alpha6* nicotinic acetylcholine receptor expression and function in a visual salience circuit. J. Neurosci. 2012, 32, 10226-10237.

97. Hone, A.J.; Meyer, E.L.; McIntyre, M.; McIntosh, J.M. Nicotinic acetylcholine receptors in dorsal root ganglion neurons include the alpha6beta4* subtype. FASEB J. 2012, 26, 917-926.

98. Liu, J.; McGlinn, A.M.; Fernandes, A.; Milam, A.H.; Strang, C.E.; Andison, M.E.; Lindstrom, J.M.; Keyser, K.T.; Stone, R.A. Nicotinic acetylcholine receptor subunits in rhesus monkey retina. Invest. Ophthalmol. Vis. Sci. 2009, 50, 1408-1415.

99. Klink, R.; de Kerchove d'Exaerde, A.; Zoli, M.; Changeux, J.P. Molecular and physiological diversity of nicotinic acetylcholine receptors in the midbrain dopaminergic nuclei. J. Neurosci. 2001, 21, 1452-1463.

100. Azam, L.; Winzer-Serhan, U.H.; Chen, Y.; Leslie, F.M. Expression of neuronal nicotinic acetylcholine receptor subunit mRNAs within midbrain dopamine neurons. J. Comp. Neurol 2002, 444, 260-274.

101. Champtiaux, N.; Gotti, C.; Cordero-Erausquin, M.; David, D.J.; Przybylski, C.; Lena, C.; Clementi, F.; Moretti, M.; Rossi, F.M.; le Novere, N.; et al. Subunit composition of functional nicotinic receptors in dopaminergic neurons investigated with knock-out mice. J. Neurosci. 2003, 23, 7820-7829.

102. Pons, S.; Fattore, L.; Cossu, G.; Tolu, S.; Porcu, E.; McIntosh, J.M.; Changeux, J.P.; Maskos, U.; Fratta, W. Crucial role of alpha4 and alpha6 nicotinic acetylcholine receptor subunits from ventral tegmental area in systemic nicotine self-administration. J. Neurosci. 2008, 28, $12318-12327$.

103. Yang, K.C.; Jin, G.Z.; Wu, J. Mysterious alpha6-containing nAChRs: Function, pharmacology, and pathophysiology. Acta Pharmacol. Sin. 2009, 30, 740-751.

104. McIntosh, J.M.; Azam, L.; Staheli, S.; Dowell, C.; Lindstrom, J.M.; Kuryatov, A.; Garrett, J.E.; Marks, M.J.; Whiteaker, P. Analogs of alpha-conotoxin MII are selective for alpha6-containing nicotinic acetylcholine receptors. Mol. Pharmacol. 2004, 65, 944-952.

105. Azam, L.; Yoshikami, D.; McIntosh, J.M. Amino acid residues that confer high selectivity of the alpha6 nicotinic acetylcholine receptor subunit to alpha-conotoxin MII[S4A,E11A,L15A]. J. Biol. Chem. 2008, 283, 11625-11632.

106. McCallum, S.E.; Parameswaran, N.; Bordia, T.; McIntosh, J.M.; Grady, S.R.; Quik, M. Decrease in alpha3*/alpha6* nicotinic receptors but not nicotine-evoked dopamine release in monkey brain after nigrostriatal damage. Mol. Pharmacol. 2005, 68, 737-746. 
107. Perry, D.C.; Mao, D.; Gold, A.B.; McIntosh, J.M.; Pezzullo, J.C.; Kellar, K.J. Chronic nicotine differentially regulates alpha6- and beta3-containing nicotinic cholinergic receptors in rat brain. J. Pharmacol. Exp. Ther. 2007, 322, 306-315.

108. Dowell, C.; Olivera, B.M.; Garrett, J.E.; Staheli, S.T.; Watkins, M.; Kuryatov, A.; Yoshikami, D.; Lindstrom, J.M.; McIntosh, J.M. Alpha-conotoxin PIA is selective for alpha6 subunit-containing nicotinic acetylcholine receptors. J. Neurosci. 2003, 23, 8445-8452.

109. Hone, A.J.; Scadden, M.; Gajewiak, J.; Christensen, S.; Lindstrom, J.; McIntosh, J.M. alpha-Conotoxin PeIA[S9H,V10A,E14N] potently and selectively blocks alpha6beta2beta3 versus alpha6beta4 nicotinic acetylcholine receptors. Mol. Pharmacol. 2012, 82, 972-982.

110. Kim, H.W.; McIntosh, J.M. alpha6 nAChR subunit residues that confer alpha-conotoxin BuIA selectivity. FASEB J. 2012, 26, 4102-4110.

111. Luo, S.; Zhangsun, D.; Wu, Y.; Zhu, X.; Hu, Y.; McIntyre, M.; Christensen, S.; Akcan, M.; Craik, D.J.; McIntosh, J.M. Characterization of a novel alpha-conotoxin from conus textile that selectively targets alpha6/alpha3beta2beta3 nicotinic acetylcholine receptors. J. Biol. Chem. 2013, 288, 894-902.

112. Plazas, P.V.; Katz, E.; Gomez-Casati, M.E.; Bouzat, C.; Elgoyhen, A.B. Stoichiometry of the alpha 9 alpha 10 nicotinic cholinergic receptor. J. Neurosci. 2005, 25, 10905-10912.

113. Elgoyhen, A.B.; Vetter, D.E.; Katz, E.; Rothlin, C.V.; Heinemann, S.F.; Boulter, J. alpha10: A determinant of nicotinic cholinergic receptor function in mammalian vestibular and cochlear mechanosensory hair cells. Proc. Natl. Acad. Sci. USA 2001, 98, 3501-3506.

114. Koval, L.; Lykhmus, O.; Zhmak, M.; Khruschov, A.; Tsetlin, V.; Magrini, E.; Viola, A.; Chernyavsky, A.; Qian, J.; Grando, S.; et al. Differential involvement of alpha4beta2, alpha7 and alpha9alpha10 nicotinic acetylcholine receptors in B lymphocyte activation in vitro. Int. J. Biochem. Cell. Biol. 2011, 43, 516-524.

115. Peng, H.S.; Ferris, R.L.; Matthews, T.; Hiel, H.; Lopez-Albaitero, A.; Lustig, L.R. Characterization of the human nicotinic acetylcholine receptor subunit alpha (alpha) 9 (CHRNA9) and alpha (alpha) 10 (CHRNAIO) in lymphocytes. Life Sci. 2004, 76, 263-280.

116. McIntosh, J.M.; Absalom, N.; Chebib, M.; Elgoyhen, A.B.; Vincler, M. Alpha9 nicotinic acetylcholine receptors and the treatment of pain. Biochem. Pharmacol. 2009, 78, 693-702.

117. Wu, C.H.; Lee, C.H.; Ho, Y.S. Nicotinic acetylcholine receptor-based blockade: Applications of molecular targets for cancer therapy. Clin. Cancer Res. 2011, 17, 3533-3541.

118. McIntosh, J.M.; Plazas, P.V.; Watkins, M.; Gomez-Casati, M.E.; Olivera, B.M.; Elgoyhen, A.B. A novel alpha-conotoxin, PeIA, cloned from Conus pergrandis, discriminates between rat alpha9alpha10 and alpha7 nicotinic cholinergic receptors. J. Biol. Chem. 2005, 280, 30107-30112.

119. Ellison, M.; Haberlandt, C.; Gomez-Casati, M.E.; Watkins, M.; Elgoyhen, A.B.; McIntosh, J.M.; Olivera, B.M. Alpha-RgIA: A novel conotoxin that specifically and potently blocks the alpha9alpha10 nAChR. Biochemistry 2006, 45, 1511-1517.

120. Callaghan, B.; Adams, D.J. Analgesic alpha-conotoxins Vc1.1 and RgIA inhibit $N$-type calcium channels in sensory neurons of alpha9 nicotinic receptor knockout mice. Channels 2010, 4, $51-54$. 
121. Callaghan, B.; Haythornthwaite, A.; Berecki, G.; Clark, R.J.; Craik, D.J.; Adams, D.J. Analgesic alpha-conotoxins $\mathrm{Vc} 1.1$ and $\mathrm{Rg} 1 \mathrm{~A}$ inhibit $N$-type calcium channels in rat sensory neurons via GABAB receptor activation. J. Neurosci. 2008, 28, 10943-10951.

122. Cuny, H.; de Faoite, A.; Huynh, T.G.; Yasuda, T.; Berecki, G.; Adams, D.J. gamma-Aminobutyric acid type $\mathrm{B}(\mathrm{GABAB})$ receptor expression is needed for inhibition of $N$-type (Cav2.2) calcium channels by analgesic alpha-conotoxins. J. Biol. Chem. 2012, 287, $23948-23957$.

123. Zheng, G.; Zhang, Z.; Dowell, C.; Wala, E.; Dwoskin, L.P.; Holtman, J.R.; McIntosh, J.M.; Crooks, P.A. Discovery of non-peptide, small molecule antagonists of alpha9alpha10 nicotinic acetylcholine receptors as novel analgesics for the treatment of neuropathic and tonic inflammatory pain. Bioorg. Med. Chem. Lett. 2011, 21, 2476-2479.

124. Napier, I.A.; Klimis, H.; Rycroft, B.K.; Jin, A.H.; Alewood, P.F.; Motin, L.; Adams, D.J.; Christie, M.J. Intrathecal alpha-conotoxins Vc1.1, AuIB and MII acting on distinct nicotinic receptor subtypes reverse signs of neuropathic pain. Neuropharmacology 2012, 62, 2202-2207.

125. Adams, D.J.; Berecki, G. Mechanisms of conotoxin inhibition of $N$-type $(\mathrm{Ca}(\mathrm{v}) 2.2)$ calcium channels. Biochim. Biophys. Acta 2013, 1828, 1619-1628.

126. Halai, R.; Clark, R.J.; Nevin, S.T.; Jensen, J.E.; Adams, D.J.; Craik, D.J. Scanning mutagenesis of alpha-conotoxin Vc1.1 reveals residues crucial for activity at the alpha9alpha10 nicotinic acetylcholine receptor. J. Biol. Chem. 2009, 284, 20275-20284.

127. Yu, R.; Kompella, S.N.; Adams, D.J.; Craik, D.J.; Kaas, Q. Determination of the alpha-conotoxin Vc1.1 binding site on the alpha9alpha10 nicotinic acetylcholine receptor. J. Med. Chem. 2013, $56,3557-3567$.

128. Ellison, M.; Feng, Z.P.; Park, A.J.; Zhang, X.; Olivera, B.M.; McIntosh, J.M.; Norton, R.S. Alpha-RgIA, a novel conotoxin that blocks the alpha9alpha10 nAChR: Structure and identification of key receptor-binding residues. J. Mol. Biol. 2008, 377, 1216-1227.

129. Azam, L.; McIntosh, J.M. Molecular basis for the differential sensitivity of rat and human alpha9alpha10 nAChRs to alpha-conotoxin RgIA. J. Neurochem. 2012, 122, 1137-1144.

130. Marx, A.; O’Connor, R.; Tzartos, S.; Kalies, I.; Kirchner, T.; Muller-Hermelink, H.K. Acetylcholine receptor epitope in proteins of myasthenia gravis-associated thymomas and non-thymic tissues. Thymus 1989, 14, 171-178.

131. Navaneetham, D.; Penn, A.S.; Howard, J.F., Jr.; Conti-Fine, B.M. Human thymuses express incomplete sets of muscle acetylcholine receptor subunit transcripts that seldom include the delta subunit. Muscle Nerve 2001, 24, 203-210.

132. Horton, R.M.; Manfredi, A.A.; Conti-Tronconi, B.M. The 'embryonic' gamma subunit of the nicotinic acetylcholine receptor is expressed in adult extraocular muscle. Neurology 1993, 43, 983-986.

133. Gattenlohner, S.; Schneider, C.; Thamer, C.; Klein, R.; Roggendorf, W.; Gohlke, F.; Niethammer, C.; Czub, S.; Vincent, A.; Muller-Hermelink, H.K.; et al. Expression of foetal type acetylcholine receptor is restricted to type 1 muscle fibres in human neuromuscular disorders. Brain 2002, 125, 1309-1319. 
134. Gattenloehner, S.; Vincent, A.; Leuschner, I.; Tzartos, S.; Muller-Hermelink, H.K.; Kirchner, T.; Marx, A. The fetal form of the acetylcholine receptor distinguishes rhabdomyosarcomas from other childhood tumors. Am. J. Pathol. 1998, 152, 437-444.

135. Gattenloehner, S.; Dockhorn-Dworniczak, B.; Leuschner, I.; Vincent, A.; Muller-Hermelink, H.K.; Marx, A. A comparison of MyoD1 and fetal acetylcholine receptor expression in childhood tumors and normal tissues: Implications for the molecular diagnosis of minimal disease in rhabdomyosarcomas. J. Mol. Diagn. 1999, 1, 23-31.

136. Gu, Y.; Hall, Z.W. Characterization of acetylcholine receptor subunits in developing and in denervated mammalian muscle. J. Biol. Chem. 1988, 263, 12878-12885.

137. Witzemann, V.; Barg, B.; Criado, M.; Stein, E.; Sakmann, B. Developmental regulation of five subunit specific mRNAs encoding acetylcholine receptor subtypes in rat muscle. FEBS Lett. 1989, 242, 419-424.

138. Sine, S.M.; Claudio, T. Gamma- and delta-subunits regulate the affinity and the cooperativity of ligand binding to the acetylcholine receptor. J. Biol. Chem. 1991, 266, 19369-19377.

139. Changeux, J.P. The TiPS lecture. The nicotinic acetylcholine receptor: An allosteric protein prototype of ligand-gated ion channels. Trends Pharmacol. Sci. 1990, 11, 485-492.

140. Arias, H.R.; Blanton, M.P. Alpha-conotoxins. Int. J. Biochem. Cell. Biol. 2000, 32, 1017-1028.

141. Jackson, M.B. Perfection of a synaptic receptor: Kinetics and energetics of the acetylcholine receptor. Proc. Natl. Acad. Sci. USA 1989, 86, 2199-2203.

142. Zhang, Y.; Chen, J.; Auerbach, A. Activation of recombinant mouse acetylcholine receptors by acetylcholine, carbamylcholine and tetramethylammonium. J. Physiol. 1995, 486, 189-206.

143. Sine, S.M.; Claudio, T.; Sigworth, F.J. Activation of Torpedo acetylcholine receptors expressed in mouse fibroblasts. Single channel current kinetics reveal distinct agonist binding affinities. J. Gen. Physiol. 1990, 96, 395-437.

144. Khalid, M.A.A. Membrane Electrochemistry: Electrochemical Processes in Bilayer Lipid Membrane. In Electrochemistry; Mohammed, A.A.K., Ed.; InTech: Rijeka, Croatia, 2013; doi:10.5772/55507. Available online: http://www.intechopen.com/books/electrochemistry/ membrane-electrochemistry-electrochemical-processes-in-bilayer-lipid-membrane (accessed on 21 April 2014).

145. Kreienkamp, H.J.; Sine, S.M.; Maeda, R.K.; Taylor, P. Glycosylation sites selectively interfere with alpha-toxin binding to the nicotinic acetylcholine receptor. J. Biol. Chem. 1994, 269, 8108-8114.

146. Groebe, D.R.; Dumm, J.M.; Levitan, E.S.; Abramson, S.N. alpha-Conotoxins selectively inhibit one of the two acetylcholine binding sites of nicotinic receptors. Mol. Pharmacol. 1995, 48, $105-111$.

147. Hann, R.M.; Pagan, O.R.; Eterovic, V.A. The alpha-conotoxins GI and MI distinguish between the nicotinic acetylcholine receptor agonist sites while SI does not. Biochemistry 1994, 33, 14058-14063.

148. Utkin, Y.N.; Kobayashi, Y.; Hucho, F.; Tsetlin, V.I. Relationship between the binding sites for an alpha-conotoxin and snake venom neurotoxins in the nicotinic acetylcholine receptor from Torpedo californica. Toxicon 1994, 32, 1153-1157. 
149. Sine, S.M.; Kreienkamp, H.J.; Bren, N.; Maeda, R.; Taylor, P. Molecular dissection of subunit interfaces in the acetylcholine receptor: Identification of determinants of alpha-conotoxin M1 selectivity. Neuron 1995, 15, 205-211.

150. Gu, Y.; Camacho, P.; Gardner, P.; Hall, Z.W. Identification of two amino acid residues in the epsilon subunit that promote mammalian muscle acetylcholine receptor assembly in COS cells. Neuron 1991, 6, 879-887.

151. Gehrmann, J.; Alewood, P.F.; Craik, D.J. Structure determination of the three disulfide bond isomers of alpha-conotoxin GI: A model for the role of disulfide bonds in structural stability. J. Mol. Biol. 1998, 278, 401-415.

152. Groebe, D.R.; Gray, W.R.; Abramson, S.N. Determinants involved in the affinity of alpha-conotoxins GI and SI for the muscle subtype of nicotinic acetylcholine receptors. Biochemistry 1997, 36, 6469-6474.

153. Hann, R.M.; Pagan, O.R.; Gregory, L.M.; Jacome, T.; Eterovic, V.A. The 9-arginine residue of alpha-conotoxin GI is responsible for its selective high affinity for the alphagamma agonist site on the electric organ acetylcholine receptor. Biochemistry 1997, 36, 9051-9056.

154. Martinez, J.S.; Olivera, B.M.; Gray, W.R.; Craig, A.G.; Groebe, D.R.; Abramson, S.N.; McIntosh, J.M. alpha-Conotoxin EI, a new nicotinic acetylcholine receptor antagonist with novel selectivity. Biochemistry 1995, 34, 14519-14526.

155. Hu, S.H.; Loughnan, M.; Miller, R.; Weeks, C.M.; Blessing, R.H.; Alewood, P.F.; Lewis, R.J.; Martin, J.L. The 1.1 A resolution crystal structure of [Tyr15]EpI, a novel alpha-conotoxin from Conus episcopatus, solved by direct methods. Biochemistry 1998, 37, 11425-11433.

156. Jacobsen, R.B.; DelaCruz, R.G.; Grose, J.H.; McIntosh, J.M.; Yoshikami, D.; Olivera, B.M. Critical residues influence the affinity and selectivity of alpha-conotoxin MI for nicotinic acetylcholine receptors. Biochemistry 1999, 38, 13310-13315.

157. Lopez-Vera, E.; Aguilar, M.B.; Schiavon, E.; Marinzi, C.; Ortiz, E.; Restano Cassulini, R.; Batista, C.V.; Possani, L.D.; Heimer de la Cotera, E.P.; Peri, F.; et al. Novel alpha-conotoxins from Conus spurius and the alpha-conotoxin EI share high-affinity potentiation and low-affinity inhibition of nicotinic acetylcholine receptors. FEBS J. 2007, 274, 3972-3985.

158. Lluisma, A.O.; Lopez-Vera, E.; Bulaj, G.; Watkins, M.; Olivera, B.M. Characterization of a novel psi-conotoxin from Conus parius Reeve. Toxicon 2008, 51, 174-180.

159. Shon, K.J.; Grilley, M.; Jacobsen, R.; Cartier, G.E.; Hopkins, C.; Gray, W.R.; Watkins, M.; Hillyard, D.R.; Rivier, J.; Torres, J.; et al. A noncompetitive peptide inhibitor of the nicotinic acetylcholine receptor from Conus purpurascens venom. Biochemistry 1997, 36, 9581-9587.

160. Teichert, R.W.; Rivier, J.; Torres, J.; Dykert, J.; Miller, C.; Olivera, B.M. A uniquely selective inhibitor of the mammalian fetal neuromuscular nicotinic acetylcholine receptor. J. Neurosci. 2005, 25, 732-736.

161. Han, K.H.; Hwang, K.J.; Kim, S.M.; Kim, S.K.; Gray, W.R.; Olivera, B.M.; Rivier, J.; Shon, K.J. NMR structure determination of a novel conotoxin, [Pro 7,13] alpha A-conotoxin PIVA. Biochemistry 1997, 36, 1669-1677. 
162. Lebbe, E.K.; Peigneur, S.; Maiti, M.; Devi, P.; Ravichandran, S.; Lescrinier, E.; Ulens, C.; Waelkens, E.; D’Souza, L.; Herdewijn, P.; et al. Structure-Function Elucidation of a New alpha-conotoxin, Lola, from Conus longurionis. J. Biol. Chem. 2014, 289, 9573-9583; doi:10.1074/jbc.M114.556175.

(C) 2014 by the authors; licensee MDPI, Basel, Switzerland. This article is an open access article distributed under the terms and conditions of the Creative Commons Attribution license (http://creativecommons.org/licenses/by/3.0/). 